\title{
El grupo político de las revistas Militancia Peronista para la Liberación y De Frente con las bases peronistas (1973-1974): una experiencia editorial y militante
}

\author{
The Political Group of the Magazines Militancia Peronista para la \\ Liberación and De Frente con las Bases Peronistas (1973-1974): an \\ Editorial and Militant Experience
}

\begin{abstract}
Resumen
El presente artículo se concentra en la experiencia del grupo político que publicó las revistas Militancia peronista para la liberación y De frente con las bases peronistas, entre los años 1973-1974. Nuestra intención es, por un lado, reflexionar brevemente sobre el desafío teórico metodológico de trabajar con revistas político-culturales que devienen objetos de estudio y, por el otro, colocadas en la perspectiva de la nueva izquierda, reconstruir los orígenes del grupo político que se conformó en torno a las revistas, para identificar ideas-fuerza que surcaron los espacios de experiencia previos y compartidos y que permiten dar cuenta de cambios y continuidades en el proceso de transformación de su identidad peronista.
\end{abstract}

Palabras claves: Grupo Político, Revistas Político-culturales, Nueva Izquierda, Identidad Política, Orígenes.

\begin{abstract}
This article focuses on the experience of the political group that published the magazines Militancia Peronista para la liberación and De Frente con las bases Peronistas, between 1973-1974. Our intention is, on the one hand, to briefly reflect on the theoretical and methodological challenge of working with political-cultural magazines that become objects of study and, on the other, placed in the perspective of the new left, to reconstruct the origins of the political group that is formed around the magazines, to identify ideas-strength that crossed the previous and shared spaces of experience and that allow to account for changes and continuities in the process of transformation of their Peronist identity.
\end{abstract}

Keywords: Political Group, Political-cultural Magazines, New Left, Political Identity, Origins. 


\section{Introducción}

El presente artículo se concentra en la experiencia del grupo político que publicó las revistas Militancia Peronista para la Liberación (MPL) y De Frente con las bases peronistas, dirigidas por los abogados Rodolfo Ortega Peña y Eduardo Luis Duhalde. Las publicaciones circularon en Argentina durante los convulsionados años setenta y fueron expresivas de la constelación alternativista, una corriente específica del peronismo revolucionario, que incluyó a diversos actores (desde organizaciones armadas y no armadas, hasta experiencias políticas, gremiales y culturales) y que, desde una perspectiva clasista y sin abandonar la identidad peronista, expresaron un proceso de radicalización original: la izquierdización del peronismo, a través de una particular articulación entre la propia tradición peronista, el marxismo y la revolución (Stavale, 2018, 2021).

Este trabajo forma parte de una investigación más amplia, que viene reconstruyendo aquella vertiente, poco explorada a comparación de otros sectores del peronismo revolucionario ${ }^{1}$. Nuestro objetivo es seguir aportando al conocimiento sobre la nueva izquierda, categoría que refiere al conjunto de fuerzas sociales y políticas diversas que protagonizaron el ciclo de movilización y radicalización política que tuvo lugar en la Argentina desde fines de los años sesenta, y que no puede reducirse sólo a sus expresiones armadas (Tortti, 2009; 2014). En efecto, asumir la perspectiva analítica de la nueva izquierda, nos permite abordar la experiencia del grupo político de MPL-DF desde una mirada y un concepto: es decir, a partir de un enfoque que subraya la heterogeneidad -puesto que no circunscribe el proceso de movilización social y radicalización política al análisis de la violencia armada- y que habilita una mirada de conjunto señalado la importancia de mirar "hacia atrás" -reconstruyendo sus orígenes- y "hacia los costados", analizando los vínculos entre la militancia revolucionaria y el movimiento social más amplio (González Canosa y Stavale, 2021).

Es que la nueva izquierda puede entenderse como el emergente de la convergencia de tradiciones político-culturales diversas que, desde los tempranos sesenta, produjo la redefinición de las identidades políticas preexistentes y habilitó el surgimiento de otras nuevas (González Canosa y Stavale, 2021). Debemos decir que aquí, entendemos que las identidades no permanecen fijas; son relacionales y deben definirse como un proceso cambiante e inestable de relaciones de identificación, que mutan al calor de la invención de una tradición y a partir del vínculo entablado con otras tradiciones, con otros actores y con prácticas pasadas y presentes (Barth, 1976; Gimenez, 2007). También subrayamos que estos procesos no pueden comprenderse ajenos a la coyuntura internacional, que hacía emerger a la revolución cubana como la partera en el nacimiento de un marxismo nacional y tercermundista ni, a escala local, a la proscripción del peronismo y el impacto que produjo la combatividad obrera (James, 2010).

Aquí nos interesa remarcar dos de los múltiples movimientos que existieron en el seno de la nueva izquierda, porque permiten comprender la emergencia de "la izquierda peronista" como

\footnotetext{
${ }^{1}$ En mi tesina de grado, estudié a las Fuerzas Armadas Peronistas FAP (Stavale, 2012) y en mi tesis doctoral la experiencia editorial y militante del grupo político MPL-DF que aquí analizamos. El objetivo de esa investigación fue reponer las representaciones políticas de la propuesta alternativista (Stavale, 2018). Actualmente, me encuentro realizando una investigación posdoctoral dedicada a la reconstrucción y análisis de la estructura organizacional del Peronismo de Base (PB) que, hasta el momento, tampoco ha sido específicamente analizada.
} 
un "campo ideológico" en el que se inscribieron los sectores del peronismo revolucionario ${ }^{2}$ (Bozza, 2014): por un lado, el surgimiento de un "marxismo nacional" (Sarlo, 2001) al interior de la izquierda, que resignificó el peronismo como un movimiento de liberación nacional, antiimperialista y con potencialidad revolucionaria (Tortti, 2014). Por otro lado, en el movimiento peronista, la evolución de agrupaciones y sectores que incorporaron concepciones del marxismo y fusionaron las expectativas del movimiento proscripto con las estrategias revolucionarias socialistas (Bozza, 2014). ${ }^{3}$ Sobre el peronismo revolucionario, existen numerosas investigaciones que han reconstruido la peronización de actores que, provenientes de otras tradiciones de origen (como la izquierda, el nacionalismo o el cristianismo) se acercaron al movimiento, abonando a la formación de las principales organizaciones revolucionarias del peronismo, desde la segunda mitad de la década del sesenta (Gillespie, 2008; Lenci, 1999; Lanusse, 2005; González Canosa, 2021; Campos, 2016). Sin embargo, no han sido tantas las investigaciones orientadas a reconstruir otros movimientos, como la izquierdización de sectores que, provenientes de las entrañas del peronismo, realizaron un proceso de selección de su propia tradición (peronista) y de otras como el marxismo, transformando las fronteras de la propia identidad política a partir de la asunción de un peronismo marxista. ${ }^{4}$

La constelación alternativista reúne a sectores que se nutrieron de militantes que, en mayor medida, provenían de las entrañas del peronismo y cuestionaron de manera temprana aspectos clave como el rol del movimiento y de Perón, en un "giro" hacia la izquierda que se tornó evidente durante los convulsionados años setenta. En términos amplios, se distinguieron (y discutieron) con otras posiciones al interior del peronismo revolucionario, como el movimientismo, corriente que interpretaba que el peronismo era revolucionario en su conjunto y Perón su líder indiscutido, minimizando las contradicciones al interior del movimiento, al valorarlas como "secundarias" (Cullen, 2008). Del otro lado, el alternativismo surgió al calor del lanzamiento de la Alternativa Independiente (AI) -una propuesta política ideada por las Fuerzas Armadas Peronistas (FAP) en 1971- y discutió con aquellas caracterizaciones, resaltando las contradicciones de clase al interior del movimiento y el rol de las "burocracias sindical y política" peronistas, como expresión de los intereses de las clases dominantes. ${ }^{5} \mathrm{~A}$ la vez, enfatizaban en el

${ }^{2}$ Alberto Bozza introduce una distinción analítica interesante entre dos conceptos que, muchas veces, se solapan o son utilizados como sinónimos. Según el autor, la categoría de "peronismo revolucionario" designa al conjunto de actores que desarrollaron sus prácticas al interior o en los márgenes del Movimiento Peronista mientras que la categoría de IP hace referencia al campo ideológico (o cultural) con el cual aquellos actores se identificaron -y en el que fueron inscriptos por Perón, por otras corrientes del peronismo y por fuerzas ajenas al Movimiento. (2014, p. 59).

${ }^{3}$ Aunque no sea un tema central para este artículo, debemos mencionar la reconfiguración de tradiciones políticoculturales como el cristianismo y el vuelco a la vida política -generalmente, a través del peronismo- de importantes sectores católicos (laicos y sacerdotes), impulsados por las transformaciones que había significado el Concilio Vaticano II y la teología de la liberación (Lenci, 1999).

${ }^{4}$ Con el concepto de izquierdización, hacemos referencia a un cauce de radicalización política particular que atravesó a actores que provenían del peronismo y que producen, de manera temprana, una transformación de lo propia identidad política a partir del vínculo con el marxismo. La aclaración es pertinente porque la idea de "izquierdización” también puede ser utilizada para reflejar los cambios en las posiciones políticas de otros sectores del peronismo revolucionario en la compleja coyuntura que se abre en 1973. A modo de ejemplo, podría ser aplicada a Montoneros - JP que, en respuesta a la ofensiva represiva desatada por el gobierno peronista, comenzó a visibilizar sus contradicciones internas respecto del rol del movimiento y de Perón (Tocho, 2020). Este proceso toma forma, sobre todo, a partir de 1974.

${ }^{5}$ Tanto el movimientismo y como el alternativismo deben comprenderse como "tipos ideales", puesto que rara vez se dieron en estado puro (Lanusse, 2005 y González Canosa, 2014). Son construcciones conceptuales que resultan 
desarrollo de "núcleos políticos fabriles" que les otorgaban una nueva centralidad a las fábricas en la tarea de desarrollar políticas revolucionarias hegemonizadas por la clase obrera (Barletta y Lenci, 2001, p. 189). De ahí emergía la necesidad de una organización alternativa al movimiento peronista que, surgida desde las bases y con cierta independencia de Perón, acentuara el carácter clasista de esa identidad política. Aunque existen valiosos estudios sobre el alternativismo (Duhalde y Pérez, 2003; Raimundo, 2004; Pérez, 2013; Stavale, 2012, 2018, 2021), aún resta mucho por analizar, pues la corriente nucleó a diversas organizaciones revolucionarias armadas y no armadas y actores políticos, gremiales y culturales que realizaron ese movimiento de izquierdización. ${ }^{6}$

Entonces, como ha apuntado Tortti, la estrategia de volver sobre los orígenes del ciclo y de las trayectorias de los actores que estudiamos, resulta potente para ilustrarlos desde una mirada procesual, en la que "la génesis interesa si contribuye a explicar el desarrollo y la dinámica de los procesos en cuestión" (2021, p. 20; Varela y Álvarez Uría, 1997). En el caso del grupo político aquí analizado, el recorrido resulta particularmente explicativo porque, como veremos, sus itinerarios expresan aquel cauce de radicalización original característico, también, al resto de los actores del alternativismo. ${ }^{7}$ Es que muchos de sus miembros comenzaron su militancia durante el período de la resistencia peronista, ${ }^{8}$ participaron de las agrupaciones surgidas en el seno del peronismo revolucionario durante los tempranos sesenta, ${ }^{9}$ articularon políticamente con otros grupos de la nueva izquierda y radicalizaron sus visiones del peronismo, a partir de estas experiencias. Pero, además, porque "sin confundir origen con explicación" (Tortti, 2021), mirar hacia atrás y reconstruir el proceso de conformación del grupo que publicó luego las revistas MPL y DF, permite identificar huellas que devienen en verdaderas pistas analíticas para

sumamente operativas para analizar la posición de los diferentes actores, al interior del peronismo revolucionario. A la vez, no podemos perder de vista que fueron categorías nativas: es decir, que tuvieron un uso corriente entre la militancia de la época. Por este motivo, al sistematizarse analíticamente, resultan potentes ya que permiten captar la forma en que los actores se auto percibieron, se agruparon e identificaron y pensaron la política (González Canosa y Stavale, 2021, p.: 16).

${ }^{6}$ La constelación alternativista se conformó por: las FAP Comando Nacional y el Peronismo de Base (PB); el Movimiento Revolucionario 17 de Octubre (MR17); el Frente Revolucionario Peronista (FRP) con presencia en el norte del país; la columna Montoneros José Sabino Navarro, una escisión alternativista y por izquierda de la organización Montoneros; agrupaciones gremiales como los obreros gráficos dirigidos por Ongaro, los empleados de Farmacia encabezados por Di Pascuale o los Telefónicos, detrás de Guillán, el Movimiento de Bases Peronista (MBP) de Mar del Plata, formado por militantes de la ex Acción Revolucionaria Peronista (ARP) de Cooke o grupos políticos y expresiones político-culturales como el periódico cordobés Evita del PB, las revistas MPL-DF, Puro Pueblo (orgánica de McJSN) o Con Todo, segunda época, también vinculado al PB. (Al respecto, es posible consultar: Luvecce, 1992; Duhalde y Pérez, 2003; Raimundo, 2004; Seminara, 2015; Stavale, 2012, 2018, 2021, Gurrucharri, Pérez, Fontana, Alfaro, 2020)

${ }^{7}$ Aunque las organizaciones y grupos que compusieron la corriente alternativista no pueden reducirse linealmente a la presencia de estos sectores -ya que en ella también confluyeron luego, otros que no provenían del peronismo resistente sino de las clases medias, marxistas o cristianos- nuestra hipótesis es que los primeros, le dieron un sello distintivo que trazó, a grandes rasgos, una modalidad específica de radicalización política (Stavale, 2021).

${ }^{8}$ Nos referimos a la "Resistencia Peronista", período abierto con la proscripción del movimiento y el exilio político de Perón, que aglutinó un proceso de refundación identitaria signado por la capacidad de la clase obrera de autoorganizarse espontáneamente y dar la lucha en pos de sus intereses, dejando una huella que se transformó e integró en la tradición combativa de la década siguiente.

${ }^{9}$ Sobre todo, las agrupaciones que surgieron de la reorganización de la Juventud Peronista, luego de la liberación de los presos del Plan Conintes en 1963 y previo a la peronización de sectores medios y de los universitarios (Bozza, 2014). Es decir: el Movimiento Revolucionario Peronista (MRP) surgido al calor del "operativo retorno" de Perón; el Movimiento de la Juventud Peronista (MJP) y la Juventud Revolucionaria Peronista (JRP). 


\section{Mariela Stavale}

comprender y analizar la posición de las publicaciones, durante la particular coyuntura en la que circularon.

El estudio de esta experiencia político editorial resulta relevante por múltiples motivos. En primer lugar, porque antes no habían sido formalmente indagadas e iluminarlas constituye de por sí un aporte. Pero, sobre todo, porque las revistas reunieron una serie de características particulares que merecen especial atención: expresaron a un grupo que no se redujo al equipo editorial (extremadamente pequeño) sino que reunió a un conjunto de actores que se identificaron con las posiciones y apuestas de MPL-DF; se constituyeron como publicaciones independientes que, sin ser una organización armada, discutieron con todas ellas, incidiendo en el debate político de la coyuntura; no se alinearon a las posiciones hegemónicas de la organización más importante del peronismo revolucionario: Montoneros-Juventud Peronista Regionales (JPr). Finalmente, porque las páginas de MPL-DF trazan un camino tensado por la ruptura del "horizonte de expectativas" abierto por el gobierno de Héctor Cámpora y expresan las redefiniciones que se produjeron, cuando la coyuntura se volvió abrupta y violentamente adversa. Como un actor político más del peronismo revolucionario, MPL primero y DF después, asumieron posiciones que desplazaron los límites de la significación "ser peronistas" en un movimiento que dejó en evidencia las suturas de una identidad que se zurcía con hilos provenientes de un "marxismo situado" 10 en el lugar de la teoría y con la experiencia del peronismo obrero, que bullía desde abajo.

La intención de este artículo es, por un lado, reflexionar sobre el desafío teóricometodológico de trabajar con revistas político-culturales que devienen en objetos de estudio y, por el otro, dar cuenta de algunas de las estrategias que hemos puesto en juego para llevar adelante esa tarea. Sobre todo, en torno a la noción de grupo político para abordar ambas revistas y las dimensiones de análisis que habilitó. Para ello y como primer paso, nos dedicaremos a plantear algunas consideraciones generales sobre el desafío de estudiar publicaciones políticoculturales, explicitando las decisiones teórico-metodológicas que hemos tomado en el proceso de construcción de nuestro objeto de estudio: en particular, la noción de grupo político y su operatividad a la hora de asumir una perspectiva dialéctica, que conciba a las revistas como un punto de llegada y de partida al mismo tiempo.

Luego, nos dedicaremos a mirar hacia atrás para reconstruir el proceso de con-formación del grupo político. En particular, abordaremos las trayectorias de Rodolfo Ortega Peña y Eduardo Luis Duhalde, por ser los directores de las revistas y los dirigentes del agrupamiento. También reconstruiremos los espacios de experiencia previos, que se transforman en verdaderos cauces para la confluencia de militantes en torno a Ortega Peña y Duhalde y que fueron delimitando las fronteras del grupo en formación. Nuestra intención será reconstruir esos espacios buscando aquellas ideas fuerza que luego hacen eco en la publicación de las revistas y en el proceso de transformación identitaria que las atravesó. Finalmente, haremos un breve recorrido por el decir de MPL-DF, para destacar los ecos de aquellas huellas que comienzan a evidenciarse antes y que se resignifican luego, en la coyuntura de las publicaciones.

\footnotetext{
${ }^{10}$ Mora González Canosa acuña esta expresión para dar cuenta de la particular articulación entre marxismo y peronismo realizada por las Fuerzas Armadas Revolucionarias (FAR) en su proceso de peronización (2021).
} 


\section{Las revistas político-culturales: construcción de un objeto de estudio}

Las fechas extremas de MPL y DF encierran un período relativamente corto: las revistas circularon un poco más de un año, entre el 14 de junio de 1973 y el 30 de julio de 1974. Sin embargo, su lectura detenida comienza a transformar los parámetros del "tiempo real". La publicación de carácter semanal coincidió con uno de los momentos de mayor radicalización social y política de los años setenta. En efecto, los 38 números de MPL y los 11 de DF materializan la experiencia de los primeros meses de gobierno peronista, luego de 18 años de proscripción política y retratan los dilemas a los que se enfrentó el peronismo revolucionario: el horizonte de expectativas que abrió el gobierno de Héctor Cámpora y su pronta fractura, signada por "la masacre de Ezeiza"; 11 la asunción del presidente interino R. Lastiri y el estrechamiento de esas posibilidades; ${ }^{12}$ la tercera presidencia de Perón y la exasperación del proceso político en detrimento de las expectativas revolucionarias del peronismo de izquierda ${ }^{13} \mathrm{y}$ las disputas en torno al significado de "ser peronistas" que, durante todo este proceso, llevaron a delante los diferentes actores del movimiento (incluyendo al propio Perón).

En este sentido, MPL y DF encarnan trágicamente, el "rostro de una época" y por ese motivo, se transforman en un instrumento privilegiado a través del cual, es posible acercarnos a la "estructura de sentimientos" ${ }^{14}$ que singaron las prácticas de los actores, en el período que

${ }^{11}$ La asunción y la renuncia de Cámpora se encontraron mediadas (y signadas) por la "masacre de Ezeiza", ocurrida el 20 de junio de 1973. En esa fecha, Perón retornó al país luego de 18 años de exilio y una multitud se dispuso a recibirlo, participando de una de las concentraciones populares más importantes de la historia argentina. Allí condensaron en un mismo espacio político, las disputas y enemistades entre la izquierda y la derecha peronista que, aunque evidentes desde la campaña electoral del Frente Justicialista de Liberación (FREJULI), pasaron a ocupar el espacio público y nacional a partir de estos hechos (Franco, 2011). Desde el palco donde Perón pronunciaría su discurso, sectores asociados a las "patotas sindicales" y fuerzas de seguridad desataron un enfrentamiento armado que tuvo por principales víctimas a los sectores nucleados en torno a la TRP (Besoky, 2016, 2019). Tras los acontecimientos, Perón se pronunció en conferencia de prensa vestido con su uniforme militar y condenó a los sectores revolucionarios marcando el fin de sus pendularidades entre la izquierda y la derecha del movimiento, que habían sido típicas durante su exilio. Sobre el accionar de la "derecha peronista" también es posible consultar a Ladeuix (2005, 2021); Robertini (2020).

${ }^{12}$ Tras la renuncia de Cámpora, Raúl Lastiri -hombre de la derecha peronista- asumió la presidencia interina y abrió un momento transicional en el que se realizaron definiciones clave: el nuevo presidente se comprometía a llamar a elecciones libres, preparando al terreno para la asunción de Perón. Entre los objetivos de esa tarea se encontraba la "depuración" de los funcionarios vinculados a la izquierda peronista; además contó con el apoyo explícito de Perón, quien dejó en claro que el programa del gobierno no equiparaba "patria peronista" con "patria socialista".

${ }^{13}$ Perón asumió la tercera presidencia en octubre de 1973 y lejos de revertir el proceso que se había puesto en marcha tras la renuncia de Cámpora, lo potenció. Durante su gestión, el conflicto interno del peronismo se proyectó a escala nacional y la escalada represiva legal y extralegal, dio un salto significativo. Lejos de las expectativas de la izquierda peronista, el gobierno siguió sosteniendo un programa económico basado en la conciliación (y no la lucha) de clases; se lanzaron leyes polémicas -como las modificaciones a la ley de Asociaciones Profesionales, que favorecía a las dirigencias gremiales- y las reformas al Código Penal, que preveía penas aún más duras que las de la anterior dictadura militar.

${ }^{14} \mathrm{R}$. Williams establece una relación dialéctica entre el concepto de "experiencia" -definido como un proceso signado por una particular relación entre el "pasado" (lecciones) y el presente (conciencia clara y activa) en un "ir y venir" que engloba permanencias y el tiempo que transformaciones- y el concepto de "cultura -o modo de vida, que atraviesa las prácticas sociales de significados, valores y creencias compartidas. La categoría clave a partir de la cual este autor establece un nexo es el de "estructuras del sentimiento"; a partir de esta noción, el autor propone una relación dialéctica entre la experiencia pasada (producto de condiciones sociales, sistema de creencias, valores) y presente, vívida, inmediata. El concepto refiere al conjunto de fuerzas mutuas, desigualmente determinantes, a 
analizamos. Retomando a Sarlo, las revistas político-culturales se encuentran incrustadas en su propio tiempo; su autenticidad "lleva las marcas de la coyuntura en la que su actual pasado era presente", informando sobre las problemáticas y expectativas que las atravesaron, cuando todo estaba por hacerse (1992). Ahora bien, estas peculiaridades propias al análisis de publicaciones se transformaron en desafíos teórico-metodológicos también específicos: ¿Cómo transformar a MPL y DF en objetos de estudio? O dicho de otra forma, ¿cómo lidiar con la doble condición, inherente a las revistas político-culturales, de ser a la vez, fuentes documentales y actores políticos susceptibles de indagación?

Una estrategia metodológica sumamente operativa para responder a este conjunto de interrogantes fue abordar a las revistas desde la noción de grupo político. En primer lugar, porque considerarlas de esta forma ha permitido comprenderlas más allá de su materialidad. En efecto, siguiendo a Gramsci en sus anotaciones sobre los intelectuales y la organización de la cultura, las actividades político-editoriales integran y coordinan diferentes "fuerzas" o aspectos que pueden ser mejor abordados, partiendo del presupuesto de que, inicialmente, existe un agrupamiento cultural relativamente homogéneo, con cierta orientación general, sobre el cual se levanta el proyecto político-cultural analizado (2012, p. 149). En la misma línea, Pluet Despatin ha apuntado que el rasgo característico de una revista reside en constituir el punto de encuentro para itinerarios individuales en torno a un "credo común" en la conformación de un deseo de expresión colectiva; la noción de agrupamiento sugiere la acción de "reunir" y evoca la idea de movimiento, dando cuenta de "la realidad viviente" de una publicación que no se reduce simplemente a su índice $(1999$, p. 2). Volviendo a MPL-DF, el agrupamiento que encaró la tarea de publicarlas, incluyó a sus colaboradores directos así como también, a quienes participaron del espacio que generaron las publicaciones y coincidieron con sus apuestas políticas. En este sentido, el grupo no puede reducirse a un equipo de trabajo, de redacción o periodístico, así como las revistas no pueden quedar asimiladas con quienes encararon la tarea editorial de producirlas. Como dijimos, tanto MPL como DF, se mantuvieron independientes de las organizaciones revolucionarias actuantes al momento de su publicación y, sin ser un partido o una estructura armada, se consolidaron como un actor dentro de la constelación alternativista e intervinieron en el debate político sentando posiciones y realizando apuestas para el campo revolucionario.

Entonces, la noción de grupo político permite pensar a las revistas como un punto de llegada y de partida al mismo tiempo: las publicaciones expresan las experiencias militantes de quienes se agruparon en torno al proyecto editorial, al tiempo que permiten visibilizar la forma en que ciertas "orientaciones generales" fueron transformándose con la "elaboración real" y el desarrollo de la actividad político-editorial. Además, colocadas en la perspectiva de la nueva izquierda, estas consideraciones permiten hacer aquel doble movimiento al que antes hicimos referencia: en primer lugar, mirar hacia atrás a partir de un análisis diacrónico, como una estrategia que permita tejer puentes con el período previo y subrayar la importancia de vincular a las revistas con la evolución política e ideológica de algunos sectores del peronismo revolucionario, mostrando los procesos sociales y políticos de los cuales emergieron y los itinerarios militantes de quienes se agruparon en torno a ellas. Como veremos, sus miembros desarrollaron una intensa actividad política como abogados laboristas o defensores de presos políticos, además de una labor intelectual revisionista que ejerció gran influencia en las discusiones políticas del peronismo de izquierda (Celecia y Waisberg, 2007; Rot, 2017). A modo

partir de la cual los sujetos estructuran sus vivencias y remite a categorías materiales que permiten significar nuestras vivencias, en un momento determinado (2001; 2003 y 2009). 
de ejemplo, en el caso de los dirigentes del grupo, Ortega Peña y Duhalde se formaron de la mano de Cooke, Hernandez Arregui, Puiggrós, entre otros, delineando una identidad política que se apropió del marxismo desde el peronismo revolucionario (Eidelman, 2004). Por otro lado, considerar a las revistas como un punto de partida nos permite realizar el segundo de los movimientos que habilita el enfoque de la nueva izquierda: mirar hacia los costados, con una perspectiva de conjunto, analizando los vínculos gestados con el resto de los actores políticos y con la coyuntura específica de las revistas. Nuestros principales ejes de indagación giran en torno a dos aspectos centrales: el programático, es decir, el programa que las revistas expresaron, defendieron y transformaron a lo largo de su publicación y el coyuntural, es decir; su anclaje en la época analizada que, además, permite concebirlas como documentos político-culturales (Stavale, 2018).

A continuación, haremos el ejercicio de "mirar hacia atrás" para reconstruir los espacios de experiencia previos y compartidos por los itinerarios militantes que se aglutinaron en torno a MPL-DF. Sin perder de vista que el historiador político debe buscar empatizar con los dilemas que enfrentan los actores, para "colocarse en aquel punto de la trama en el que, para ellos, la historia está por hacerse" (Pastoriza, 2011, p. 245) buscaremos visibilizar algunas ideas fuerza que fueron punteando la trayectoria de los integrantes del grupo y se refractaron luego, como "experiencia articulada", en el decir de las revistas (Williams, 2001, p. 20). Para nombrar algunas de ellas, el vínculo entre liberación nacional-revolución social y el rol del marxismo en las apuestas de un peronismo que se quería revolucionario, la preocupación por la autonomía política de la clase obrera peronista o la apuesta por la unidad revolucionaria, fueron inquietudes que delinearon el itinerario político de Ortega Peña y Duhalde y también del resto de sus integrantes con quienes convergieron en espacios de experiencia previos y compartidos como "la Gremial de Abogados" o la revista Nuevo Hombre.

\section{Las tramas del grupo político MPL-DF: itinerarios militantes y espacios de experiencia}

Como adelantamos, las revistas MPL-DF respondieron a los criterios que Antonio Gramsci plantea para el tipo de medio "político-crítico": la existencia de un cuerpo de redactores especializados que hayan alcanzado cierto grado de homogeneidad cultural y representen un punto de llegada en el desarrollo de un movimiento cultural (2012, pp. 161-162). En el caso de nuestras publicaciones, esta exigencia puede analizarse a través de un doble registro: el del equipo editorial -extremadamente pequeño- y el del grupo político. En el primer caso, el cuerpo de editores se reducía a Ortega Peña, Duhalde y los hermanos de éste, Marcelo y Carlos María. Más aún, en la práctica, el producto final tenía mucho de Ortega Peña y Duhalde: ambos eran quienes escribían la mayoría de las notas, quienes la habían diagramado y quienes realizaban los mayores esfuerzos para que el proyecto estuviera en la calle. Es que la militancia los había mantenido unidos desde los tempranos sesenta, forjando una relación de identidad que no se reducía sólo a la identificación política. La homogeneidad cultural, política e intelectual a la que habían llegado era tal, que se materializaba indivisible en la labor conjunta:

Rodolfo y Eduardo tenían una particularidad que yo no he conocido en otra gente... en aquella época por supuesto no había computadoras, teníamos las máquinas de escribir... 


\section{Mariela Stavale}

y entonces empezaba a escribir... y esto pasaba también en los escritos judiciales... empezaba a escribir uno y de repente le avisaban "te sonó el teléfono" entonces se sentaba a escribir el otro y después ni ellos mismos sabían qué parte había escrito cada uno. (Duhalde M, 2014)

Duhalde también recuerda que el equipo había contado con la colaboración de dos militantes del PC, Sara Jorge y Berta Sofovich -quienes, previamente, habían fundado la editorial Lautaro- y de dos diseñadores que ayudaron a pensar el formato del seminario.

El segundo registro, el del grupo político, amplía los márgenes a la participación de dos tipos de integrantes: aquellos que trabajaban directamente (escribiendo notas) y quienes lo hacían indirectamente (aportando información, recursos económicos, defendiendo al medio de las acusaciones judiciales - tal fue el caso de Carlos González Gartland, quien se transformó en "el abogado de MPL" (González Gartland, 2015)- o simplemente, acompañando con opiniones y críticas. Así, quedó conformado por: Vicente Zito Lema, Mario A. Hernández, Roberto Sinigaglia, Gustavo Roca, Carlos González Gartland (todos también miembros de la Gremial de Abogados), Ricardo Carpani, Mónica Peralta Ramos (socióloga y economista) que aportaba en las notas de fondo, al igual que Alicia Eguren, el abogado laboralista Héctor Recalde, Miguel Ángel Radrissani Goñi (abogado defensor de presos políticos), Diego Muñiz Barreto (empresario y colaborador económico).

Al mismo tiempo, el grupo se nutría de militantes de diferentes organizaciones revolucionarias como Rubén Dri (referente del PB), Rodolfo Mattarollo (abogado defensor de presos políticos, cuya trayectoria había comenzado en el peronismo y terminó vinculada al PRTERP), Ignacio Vélez (militante de la columna Montoneros José Sabino Navarro -McJSN), Osvaldo Acosta (abogado del PB y miembro del Movimiento Villero Peronista), Elsa Portugheis y Ricardo Yacomini (militantes de las Fuerzas Armadas de Liberación -FAL), quienes fueron "enviados" por la organización a trabajar en MPL y continuaron con la experiencia de DF:

Vicente [Zito Lema] era un amigo... el cura también [en referencia a Dri]... como ellos un montón de compañeros-colaboradores que realizaban aportes que a veces llegaban solos y a veces les pedíamos sobre determinados temas... que si bien no integraban el staff formal de la revista, sí tenían una pertenencia al grupo... al proyecto político de la revista. (Duhalde M., 2014)

Ahora bien, más allá de que las revistas no puedan reducirse a la figura de sus directores, las trayectorias de Ortega Peña y Duhalde tienen una importancia central que no es posible desconocer a la hora de analizar esta experiencia editorial. A partir de la idea de grupo político, podríamos pensar que, como en todo agrupamiento, éste también tuvo un espacio de dirección que fue ocupado por ambos. Ortega y Duhalde no sólo fueron claves por dirigir ambas revistas sino también por ser quienes "simbolizaban el proyecto político revolucionario" del grupo (Zito Lema, 2013). Con una expresión que los retrata, Rubén Dri recuerda que ambos eran una "figuración importante" y que además eran "inorganizables" o, mejor dicho, que "generaban ellos mismos una organización" (Dri, 2014). En efecto, ambos aglutinaron a buena parte de los miembros del agrupamiento y le imprimieron una impronta particular, derivada de la experiencia compartida dentro del peronismo. Al repasar la trayectoria de ambos, es posible identificar ciertos núcleos argumentales o huellas que luego, frente a la densidad sociopolítica de los años setenta, 


\section{Mariela Stavale}

se refractaron a partir de nuevas direcciones, transformadas por los debates que atravesaron a las revistas.

Tanto Ortega Peña como Duhalde iniciaron su trayectoria alistados en el espacio de la izquierda nacionalista. Las influencias de Cesar Marcos, Scalabrini Ortiz, Hernández Arregui y John William Cooke determinaron un diálogo particular con el nacionalismo y el marxismo, en un claro acercamiento al peronismo, que los interpeló. La búsqueda tuvo por eje aunar "lo mejor del peronismo con lo mejor del marxismo" $\mathrm{y}$, en ese camino, ambos tejieron vínculos diversos $\mathrm{y}$ participaron de varios espacios políticos (Rot, 2016, p. 16). Una primera experiencia fue su incorporación a la organización Centros Organizados Nacionales de Orientación Revolucionaria (CONDOR), alentada por Hernández Arregui e integrada por peronistas y marxistas. Como primera iniciativa, el dueto de abogados propuso la incorporación de Cooke que recién regresaba de Cuba y se erigía como una figura que aglutinaba el diálogo entre aquellas tradiciones. Sin embargo, el líder de la resistencia peronista no aceptó el invite por considerar un error político que, en un documento fundacional, CONDOR hiciera explícita su reivindicación al marxismo. Lo que parece una paradoja - por la trayectoria del propio Cooke- no lo fue, y se estableció como una enseñanza clave que atravesó la práctica de Ortega Peña y Duhalde, replicándose luego, para el grupo político de MPL-DF. A modo de respuesta, Cooke redactó una carta en la que realizó algunas definiciones; entre ellas, que la realidad política del país requería "evitar definiciones precisas" y sostenía que esa necesidad se correspondía con la realidad del peronismo, definido como esencialmente ambiguo. A la vez, el dirigente revolucionario distinguía de manera temprana, dos peronismos que, aún, estaban íntimamente vinculados: uno "chato, ampuloso, mediocre", vinculado al estilo de la dirigencia política y gremial del movimiento; el otro que "bulle desde abajo", en las resistencias populares y huelgas y que es "esencia, no apariencia". Finalmente, sobre la asunción del marxismo, apuntó:

[...] podemos decir en una tribuna que queremos eliminar el capitalismo, librarnos del imperialismo y darle los bienes de producción al pueblo y arrancaremos aplausos. Ese mismo auditorio, si nos declaramos marxistas, nos mirará con desconfianza [...] y en lugar de ver allí la culminación del peronismo pensará que hemos cambiado de chaquetilla. Irracional, ilógico y todo lo que se quiera, pero exacto. (Rot, 2016, pp. 2122)

El documento condensaba núcleos claves del pensamiento de Cooke, que constituyeron una importante influencia para los futuros dirigentes del grupo analizado. Entre ellas, la caracterización de un movimiento heterogéneo, pero potencialmente revolucionario por su contenido obrero; la existencia temprana de dos peronismos: uno de las castas dirigentes y el otro, proveniente del espontaneísmo de las bases que, sin embargo, todavía no renegaba por completo de la existencia del primero y, finalmente y debido a esto, el rol de la "burocracia peronista" que no era desestimado por Cooke. Por el contrario, lo analizaba en clave marxista y distinguía la realidad empírica de los trabajadores, de sus "intereses objetivos". La apuesta de "hacer bullir" al "verdadero peronismo" implicaba, en efecto, esa superación dialéctica, que corregiría la ambigüedad del peronismo en torno a los intereses (revolucionarios) de la clase trabajadora. 
Estas definiciones tempranas -junto a otras, como la convicción de que la liberación nacional y la revolución social eran instancias de un mismo proceso- ${ }^{15}$ se hicieron eco en el análisis de MPL-DF que lejos de esconder su adscripción a Cooke, la tornó explícita. ${ }^{16} \mathrm{Su}$ influencia se multiplicó en la formación de quienes tuvieron un vínculo fluido con él. Sin adelantarnos, podemos identificar algunas de sus huellas en el itinerario de la mayor parte de los miembros del grupo: el esfuerzo por expandir el enfoque peronista sin abandonar esa identidad política y la apuesta por una redefinición revolucionaria de la identidad peronista a partir de su componente obrero; el reconocimiento de un marxismo nacionalista, tercermundista y "situado", es decir, en tanto lentes a partir de los cuales, comprender la realidad; el vínculo entre peronismo y revolución, puesto que para los futuros miembros del grupo analizado, liberación nacional y social también eran indivisibles y, finalmente, la preocupación por la relación ambigua entre la base y los dirigentes sindicales.

La influencia de Cooke fue tal, que Ortega Peña y Duhalde renunciaron a "asumir una identidad política como izquierda nacional, para alcanzar una definición como peronistas revolucionarios" (Rot, 2016, p. 25). Esta definición los alejó, también, de Hernández Arregui (simpatizante, pero no orgánico del peronismo) y de otros integrantes del grupo con influencias trotskistas ${ }^{17}$. A la vez, entre los años 1963-1966, el dueto de abogados priorizó su militancia en dos frentes: por un lado, aun bajo el sello CONDOR, aceitaron un vínculo fluido con el reciente Movimiento Nacionalista Revolucionario Tacuara (MNRT); ${ }^{18}$ por el otro, desempeñándose como abogados laboristas en la CGT de Vandor.

Respecto del primer frente y siguiendo a Rot, observamos que Ortega y Duhalde compartieron algunas posiciones políticas con el MNRT, sobre todo en el análisis del movimiento y de la figura de Perón. Las coincidencias los llevaron a acercarse a la organización armada, asumiendo la defensa de uno de sus dirigentes: Jorge Caffati, detenido tras la primera operación de la organización. ${ }^{19}$ Es interesante señalar que, gracias a la defensa del militante peronista, Ortega y Duhalde conocieron a Carlos González Gartland -futuro integrante del grupo

${ }^{15}$ Muchas de las concepciones de Cooke fueron tributarias de su experiencia en Cuba, que dejó vestigios que lo acompañaron durante toda su trayectoria (Sorín, 2014)

${ }^{16}$ En efecto, como veremos luego, el nombre escogido para la publicación que vino a reemplazar a MPL tras su clausura: De Frente rendía homenaje al periódico que, con el mismo nombre, publicó Cooke durante la resistencia peronista. En esta línea, la información editorial de la revista afirmaba su "segunda época": un gesto que no sólo hacía referencia a una continuidad vedada por la clausura de MPL sino, también, al líder de la resistencia (Ver: Stavale, 2018b)

${ }^{17}$ Como Ricardo Carpani (quien, sin embargo, después se sumará al grupo MPL-DF), Oscar Balestrini (futuro militante de las FAP) y Rubén Bortnik. Ellos, por entonces, seguían reclamando un contenido de clases revolucionario, contra el nacionalismo burgués peronista (Celecia y Waisberg, 2007, p: 82; Rot, 2016, p. 25)

${ }^{18}$ El MNRT fue una escisión de la organización falangista Tacuara. Tras la ruptura por izquierda con esa organización, se consolidaron como organización política en 1962 y en agosto de 1963 realizaron su primera (y única) operación armada, con el asaltando al Policlínico Bancario en el marco del "Operativo Rosaura". El saldo de la acción fueron dos guardias muertos y la detención de Jorge "el Turco" Caffati -uno de sus máximos dirigentes. Ya en los setenta, la trayectoria de Caffati fue calve en el debate entre alternativistas-movimientistas. Integrado a las FAP, Caffati radicalizó sus posiciones en torno a la Alternativa Independiente y terminó protagonizando uno de los tantos desgajamientos de la organización; su grupo fue conocido como "los iluministas" en referencia a estas posiciones (Stavale, 2012).

${ }^{19}$ La primera operación fue un asalto al Policlínico Bancario de Buenos Aires, con el objetivo de conseguir armas y dinero. La operación tuvo como consecuencia accidental, la muerte de un empleado de seguridad del policlínico (Gasparini, 2006). Por otro lado, debemos destacar que Jorge "el Turco" Caffati se incorporó luego a las FAP y fue uno de los mentores y responsables del lanzamiento de la Alternativa Independiente: propuesta que le dio nombre a la constelación de la que MPL-DF formaron parte. 
político- quien, para ese entonces, se desempeñaba como secretario del juzgado en el que radicaba la causa ${ }^{20}$; paradójicamente, sus trayectorias se vincularon a partir de este momento. Respecto del accionar conjunto entre CONDOR y MNRT, podemos afirmar que fue una experiencia que hizo priorizar coincidencias sobre diferencias y puede evaluarse como un nuevo intento, en el vínculo entre el peronismo revolucionario y el marxismo. En este punto, su manifiesto fundacional afirmaba que "no ser peronista y pretender ser revolucionario es hoy, como ayer, un dilema a gusto con la oligarquía, insoluble para la izquierda e irracional para un verdadero marxista" (Rot, 2016, p. 28; Celecia y Waisbert, 2007, p. 79). Más allá de las coincidencias, la relación entre CONDOR y el MNRT no prosperó. ${ }^{21}$ Ortega y Duhalde sostuvieron su adscripción a CONDOR un tiempo más y constituyeron el Centro de Estudios Históricos Felipe Varela, adherido a aquel, con el objeto de darle mayor difusión. En este marco, saldrán publicados 5 números de la revista La Unión Americana, órgano del centro. ${ }^{22}$

El segundo frente de militancia dentro del peronismo los llevó a trabajar como abogados laboristas para la CGT dirigida por Vandor. Esta participación comprometió una concepción movimientista del peronismo, que planteó una relación de debate con todos sus sectores, incluyendo las dirigencias sindicales. El dato es muy interesante porque, en la coyuntura de los años setenta, tanto Ortega como Duhalde y el resto del grupo político serán explícitamente críticos del movimientismo. En efecto, la revista MPL apeló a la trayectoria política de los miembros del grupo dentro del peronismo, como una estrategia discursiva y un recurso de autoridad en el debate con los actores que, durante el tercer gobierno peronista, seguían sosteniendo posiciones movimientistas. A modo de ejemplo, se referían irónicamente a todos ellos (incluyendo a Montoneros-JPr) como "los recién llegados al peronismo" (Stavale, 2018).

Lo cierto es que, durante los primeros años sesenta, Ortega y Duhalde tuvieron una valoración positiva del movimiento sindical, apostando a influir sobre las conducciones gremiales, sorteando las diferencias coyunturales para llegar a la clase obrera organizada, con el objetivo de profundizar un proceso de liberación nacional y social. De hecho, esta valoración tuvo gran impulso con la reactivación del movimiento obrero que, desde el programa de Huerta Grande en $1962^{23}$ había ido forjando una multiplicidad de medidas de lucha, que se condensaron durante todo el año 1964, incluyendo tomas de fábrica y paros. Ambos abogados participaron

${ }^{20}$ González Gartland apunta que su trayectoria política y militante se vio profundamente transformada tras largas conversaciones mantenidas con los presos políticos y fundamentalmente, con Caffati, a quien señala como un "futuro cuadro" del PB. Su militancia había estado vinculada al Partido Socialista con el que rompe luego de tales influencias. A su vez, también en esos años, renuncia al cargo en la Secretaría del juzgado al caer en cuenta "de que estaba siendo un agente de la represión clasista y yo me consideraba del otro lado, es decir, con la clase antagónica. Así me dije, 'esto es incompatible con la conducta que debe tener un socialista'... y renuncié" (González Gartland, 2015)

${ }^{21}$ Rot señala como un factor de peso el hecho de que la mayor parte de la dirección de MNRT haya estado presa (2016).

${ }^{22}$ La revista tuvo por objeto contribuir a que la clase obrera pueda reconocerse en la continuidad de sus luchas, triunfos y derrotas y concentró dos símbolos del revisionismo histórico que ambos venían practicando como intelectuales comprometidos: el nombre de la publicación -consigna agitada por Felipe Varela- y su rúbrica: la frase "Naides más que naides", de Artigas, con la aclaración de que se trataba de un lema montonero (Rot, 2016, p. 32; Celecia y Waisberg, 2007, pp. 117-118).

${ }^{23}$ El programa de Huerta Grande -conocido de esta forma por la localidad cordobesa donde se realizó el plenario sindical- proponía entre otras cosas la nacionalización de los bancos y de los sectores claves de la economía, la expropiación de latifundios sin ningún tipo de compensación y la planificación de la economía argentina en función de los intereses nacionales. Este programa -ante la presión de las bases- había sido impulsado por las 62 Organizaciones dirigidas por Vandor. 


\section{Mariela Stavale}

activamente de muchas de estas medidas, asumiendo la defensa de obreros y gremialistas que quedaban detenidos.

Otra arista de su participación dentro del gremio fue la investigación que ambos realizaron sobre la desaparición del militante metalúrgico Felipe Vallese, en 1962. El caso fue paradigmático no sólo porque Vallese continúa desaparecido sino porque el libro Felipe Vallese, Proceso al Sistema fue editado y publicado por la Unión Obrera Metalúrgica (UOM), gremio sospechado de cómplice por los sectores antiburocráticos que afirmaban que Vandor no había movilizado lo suficiente para encontrar al militante metalúrgico ${ }^{24}$. Según Rot, el libro de Ortega y Duhalde no sólo se hizo tributario de las críticas de los sectores antiburocráticos -que lo interpretaron como un intento de Vandor por bloquear cuestionamientos- sino también, "de algunos sectores del peronismo ortodoxo que se indignaron porque dos conocidos ideólogos de la izquierda firmaran una publicación prohijada por la UOM" (Rot, 2016, p. 40). Más allá de estos matices, cierto es que el dueto de abogados apostó por la labor con la dirigencia sindical que, para la época, era fuertemente cuestionada por el peronismo radicalizado y la izquierda en general. De hecho, Vandor se convirtió en un ejemplo claro de "burócrata", figuración que más adelante adquirió centralidad -incluso y sobre todo, desde las páginas de las revistas analizadas.

En efecto, y a la luz del derrotero político que aquí analizamos, interesa resaltar la importancia de este espacio de experiencia, por las marcas que dejó en los dirigentes políticos del grupo MPL-DF. Más allá de las posiciones antiburocráticas que Ortega y Duhalde asumieron tiempo después, pensamos que algunas ideas vinculadas a esta experiencia pueden ser pistas analíticas para entender sus posicionamientos políticos en la coyuntura de los años setenta. Como hemos dicho, durante los años 1963-1966, la dirigencia sindical se había establecido como la principal fuerza política representativa de los trabajadores peronistas. Durante esos años, Ortega y Duhalde habían adoptado como propia la lectura realizada por Roberto Carri en Sindicatos y poder en Argentina, libro que además habían prologado. Allí, el sociólogo peronista afirmaba que la particularidad del sindicalismo luego de la caída de Perón era el de ser la vanguardia de las clases populares (incluso contra la voluntad de los dirigentes gremiales) hasta que no surja otro organismo -en particular, un partido político propio de la clase obrera- que asuma ese rol. Siguiendo a Rot, observamos que los abogados laboralistas sumaron a esta caracterización "una convicción de corte soreliano" (para nosotros, más bien leninista) que sostuvo que "ninguna acción huelguística alcanzará trascendencia política si carece de dirección emancipatoria". En efecto, el autor apunta que estos posicionamientos no reñían con la lectura clásica del marxismo en el frente sindical (Rot, 2016, pp. 39-40).

Estas convicciones explican la labor de ambos en la CGT vandorista porque, en efecto, el proyecto de Vandor era crear un "partido obrero" íntimamente vinculado a los sindicatos (James, 2010, p.: 263). Si bien esta postura se inspiraba en experiencias del peronismo como la del Partido Laborista ${ }^{25}$ y en la convicción sobre el carácter multiclasista del movimiento, la novedad

${ }^{24}$ Celecia y Waisberg reconstruyen las posiciones de Duhalde respecto del debate el grado de responsabilidad de la UOM en la desaparición de Vallese y dejan entrever que el dueto de abogados no coincidía con la acusación que los sectores duros del sindicalismo peronista realizaban sobre la UOM. En efecto, los autores afirman que el dueto de abogados discutió con la investigación que Leopoldo Barraza realizó sobre los hechos en el periódico Compañero (según Duhalde, Barraza "construyó la teoría de la responsabilidad de la UOM") negando las imputaciones que por negligencia y desidia cayeron sobre la conducción del sindicato [Celecia y Waisberg, 2007, p. 96].

${ }^{25}$ El Partido Laborista fue creado en 1945 como expresión política del movimiento obrero, con el objetivo de sostener la candidatura presidencial de Perón. Representaba a los sectores sindicales organizados que habían 
radicaba en la pretensión de una independencia política respecto de Perón. Aunque la militancia política posterior condujo a que ambos realicen una caracterización del movimiento sindical y de la burocracia diametralmente opuesta, podríamos aventurar que ciertas apuestas, como la creación de un partido político de los trabajadores o incluso la noción de un "peronismo sin Perón”, hicieron eco en el ideario político de MPL-DF que, desde una perspectiva de izquierda, predicó por la autonomía de la clase obrera peronista.

A su vez, la experiencia en las entrañas del peronismo y del movimiento obrero organizado abonó al conocimiento sobre la realpolitik peronista, tanto respecto de la dirigencia gremial como del propio Perón. En efecto, como estrategia para desactivar la pretensión de autonomía sindical vandorista, Perón alentó a los sectores más duros del peronismo y en 1964 nombró a Héctor Villalón como su delegado personal, al tiempo que reorganizó al peronismo en manos de un Cuadrunvirato dominado por Framini, dirigente combativo del sindicalismo. Villalón, estructuró una estrategia insurreccional que tenía como objetivo clave el retorno de Perón. Sin embargo, a último momento, un cambio de estrategia del líder amplió el Cuadrunvirato y concedió hegemonía interna al vandorismo, poniendo en un difícil trance a los sectores combativos y provocando sucesivas deserciones (Duhalde y Pérez, 2003, p. 45). Entre los grupos que se escindieron, cobró importancia el de Gustavo Rearte dado que desde la conducción de la Juventud Revolucionaria Peronista (JRP) impulsó la constitución del Movimiento Revolucionario Peronista (MRP) y, vinculado a éste, las primeras FAP de $1964 .^{26}$ Respondiendo a la postura de colaborar con todos los actores del movimiento peronista, Ortega Peña y Duhalde "sumaron su participación y esfuerzo" al proyecto de conformar las FAP, asistiendo a su pronta desactivación producto de las tácticas del líder exiliado (Celecia y Waisberg, 2007, p. 85). Lo que nos interesa señalar es que, durante estos años, se puso en evidencia la estrategia pendular de Perón y esta experiencia acumulada no será para nada desdeñable cuando, en la coyuntura de 1973 y 1974, el peronismo revolucionario se enfrente nuevamente a los desaires del viejo caudillo.

El golpe de Estado que en 1966 dio paso al gobierno del General Onganía puso fin a la colaboración de ambos abogados con la CGT vandorista. Según Rot, desde entonces Ortega Peña y Duhalde "iniciaron un camino inversamente proporcional al de Vandor. Cuanto el gremio más se acercaba a los golpistas, ellos más se alejaban del sindicato" (2016, p. 108). La nueva dictadura redireccionó la militancia de ambos, que priorizaron la labor intelectual como revisionistas. ${ }^{27}$

participado del 17 de octubre. A partir de 1946 -cuando Perón asumió la presidencia- buscó disolver los partidos políticos que lo habían llevado al poder, buscando conformar un partido único y vertical (el peronista). Esta imposición fue rechazada por el laborismo, que se negaba a perder autonomía. Luego de tensiones y presiones intensas, la conducción nacional del partido acató la orden de Perón y terminó disolviéndose, en 1947.

${ }^{26}$ Las FAP que surgen en 1964 tuvieron una experiencia efímera y poco conocida. Sin embargo, ese recorrido es clave, puesto que puede considerarse como un antecedente de las FAP que en 1968, se aventuraron en los montes tucumanos, buscando instalar un foco guerrillero rural (para más información sobre este vínculo y sobre la experiencia de FAP, ver: Stavale, Mariela, “Las Fuerzas Armadas Peronistas”, pp. 14-15).

${ }^{27}$ Este trabajo había comenzado en los tempranos sesenta (con la producción de notas referidas a la injerencia de la banca Baring Brothers en la economía nacional, la revista La Unión Americana o la publicación de los libros como El asesinato de Dorrego (Poder, oligarquía y penetración extranjera en el Río de La Plata) y Alberdi, los mitristas y la guerra de la Triple Alianza, en 1965 pero se profundizó en los años posteriores al golpe. El revisionismo del dueto buscaba una "visión totalizadora" fundada en la necesidad de comprender el pasado para hacer lo propio en el presente. A su vez, Duhalde señala que ambos observaban como falencia "una falta de interpretación de la historia argentina desde el marxismo" (Celecia y Waisberg, 2007, p. 112). En efecto, en 1966 solidificaron su 
Como veremos a continuación, el año 1968 abre un período clave. Durante este año resurgieron las FAP - organización armada peronista que puede ser interpretada como una "organización puente o bisagra" entre dos momentos históricos: el de "la resistencia" y el de la consolidación de las organizaciones setentistas (Stavale, 2012, pp. 46-47) - y la Confederación General del Trabajo de los Argentinos (CGT-A), que se transformó en un nuevo eje de referencia para la nueva izquierda (Bozza, 2009). En efecto, Ortega Peña y Duhalde entablaron lazos directos con sus jefes más representativos, como Raimundo Ongaro y Agustín Tosco aunque, como veremos, no llegaron a integrarse al trabajo que allí realizaban los abogados de la central antiburocrática.

\section{Convergencias militantes: hacia la conformación del grupo MPL-DF}

En Argentina, el período 1968-1973 se recorta por su densidad histórica y por ser el escenario de un proceso de radicalización política que se potenció durante estos años. Como un primer signo de época, la mencionada CGTA reconfiguró el escenario sindical, expresó un nuevo realineamiento gremial opositor al vandorismo e intransigente respecto de la política del gobierno y devino en un espacio de convergencia para la militancia del peronismo revolucionario, los sectores de la izquierda sindical y el movimiento estudiantil (Bozza, 2009, p. 188). Pero, además, porque la central obrera se transformó en un afluente fundamental para la aceleración política que terminó eclosionando en 1969, con las insurrecciones populares conocidas como RosariazoCordobazo-Rosariazo (Balvé, 1989).

Las consecuencias de estos ciclos de protesta fueron múltiples y se expandieron rápidamente: surgieron puebladas, movimientos insurreccionales y las organizaciones revolucionarias armadas y no armadas, peronistas y marxistas que, además, entablaron "una relación dinámica y dialéctica" con el movimiento obrero (Pozzi y Schbeider, 2000). Pero, además, sobre todo en Córdoba desde 1970, sectores proletarios profundizaron, desde las bases y en las fábricas, el cuestionamiento a la hegemonía de las conducciones gremiales, desarrollando una nueva estrategia y corriente sindical: el clasismo que, basada en los postulados de la lucha de clases, tejió vínculos con las fuerzas políticas y gremiales peronistas y marxistas, ligadas a la nueva izquierda (Laufer, 2021). En efecto, como hemos mencionado antes, los actores que integraron la constelación alternativista desde 1971 tensionaron los márgenes de su identidad peronista en un acercamiento al clasismo que venía desarrollando posiciones antiburocráticas, antiimperialistas y antidictatoriales, desarrollaba direcciones combativas y planteaba un programa revolucionario, a partir de la hegemonía de la clase obrera (Brennan y Gordillo, XXX; Laufer, 2021).

En esta agitada coyuntura, las trayectorias de Ortega Peña y Duhalde se unieron a las del resto de los integrantes del grupo MPL-DF al calor de varios espacios de experiencia. Uno de ellos que será clave, fue el de la defensa de presos políticos durante la dictadura militar. Siguiendo a Chama, podríamos afirmar que la institucionalización de la actividad defensista se

militancia cultural a partir del emprendimiento editorial Sudestada, sello que publicó escritos históricos y políticos de orientación revisionista y nacional, incluyendo sus producciones. Entre ellas: Felipe Varela contra el imperio británico, Las masas de la Unión Americana enfrentan a las potencias europeas, Folklore argentino y revisionismo histórico, La montonera de Felipe Varela en el cantar popular y Las guerras civiles argentinas y la historiografía y la obra que más trabajo les demandó: Facundo y la montonera: Historia de la resistencia nacional a la penetración británica (Rot, 2016, p. 42). 
produjo a partir de dos frentes: el que se desarrolló con el cuerpo de abogados vinculados a la CGTA (1968-1970) y el que se estableció en la Asociación Gremial de Abogados (1971-1973) (Chama, 2010). Aunque, como veremos, el vínculo político que fue sedimentando las fronteras del grupo analizado se forjó a partir de la militancia en "la Gremial", el cuerpo de abogados de la CGTA fue un antecedente importante. En efecto, futuros miembros del agrupamiento analizado, como Roberto Sinigaglia o Mario Hernández, participaron de esa experiencia que terminó disgregándose hacia 1970, desactivada, sobre todo, por la política represiva de la dictadura militar que recayó sobre sus principales dirigentes y sobre sus abogados. Este aspecto es importante porque, rápidamente, generó una "trama solidaria" entre letrados que incidió en la constitución de "la Gremial". Además, numerosos profesionales con reconocida trayectoria política en el peronismo o las izquierdas comenzaron a asumir indistintamente, la defensa de militantes pertenecientes a los grupos armados (Chama, 2007, p. 10). Estos vínculos forjaron criterios de defensa que hicieron eco en la nueva asociación de abogados y, particularmente, en el grupo de MPL-DF; en términos generales, las representaciones legales no se correspondían con la pertenencia político-partidaria de los detenidos sino a una combinación más amplia de afinidades político-ideológicas, el reconocimiento de la lucha armada como expresión opositora y la confianza personal entre el abogado y el detenido.

Para 1970, muchos de los miembros del futuro grupo MPL habían desarrollado contactos estrechos con los cuadros dirigentes de los grupos revolucionarios. En efecto, uno de sus dirigentes, recuerda que para esa época tenían contacto con las principales organizaciones armadas: FAP, Montoneros, Partido Revolucionario de los Trabajadores - Ejército Revolucionario del Pueblo (PRT-ERP) y finalmente, las Fuerzas Armadas Revolucionarias (FAR), organización guevarista que había iniciado su proceso de peronización y con la que tuvieron importantes coincidencias en ese período (Stavale, 2018; González Canosa, 2021). Por otro lado, la escalada represiva de la dictadura militar se afianzó tras el cambio de década y dio un salto en 1971, constituyendo un disparador para la formación de "la Gremial". González Gartland afirmó que, en esta coyuntura represiva, los abogados que ejercían las defensas no sentían el respaldo de la Asociación de Abogados de Buenos Aires, que mantenía una posición "más bien refractaria a definirse ante las continuas intimidaciones y atentados sufridos por los abogados defensistas (González Gartland, 2015). Por su parte, Zito Lema coincide y recuerda que:

Un núcleo de abogados [...] vemos que en el momento en que se da la más potente represión, siempre comparativamente ¿no?, hacemos un análisis y vemos que tanto la Asociación de Abogados como el Colegio de Abogados, por su formación social y política, no se comprometían en la medida en que el momento histórico demanda, por la defensa de los presos políticos [...] decidimos hacer una agrupación más homogénea, más si se quiere... comprometida, en la que van a integrarse los abogados que sí hacíamos las defensas específicamente de las organizaciones político- militares de la época. (2015)

La labor en "la Gremial" mantuvo los criterios del período previo: las defensas se asumían de manera indistinta a la pertenencia partidaria de los y las detenidos/as y la única condición era que fueran militantes del campo popular y revolucionario. De esta forma, la actividad defensista no sólo auspició el surgimiento del "abogado comprometido" (Chama, 2012, p. 13); sino que, también, fue sedimentando en muchos de sus miembros, una apuesta política que, en palabras de 
González Gartland, puede expresarse como la búsqueda deliberada de "cohesionar a la izquierda peronista y la izquierda socialista, socializando a los peronistas y peronizando a los socialistas". En efecto, el abogado también remarca que el espacio de "la Gremial" y el de las revistas MPLDF compartieron "las mismas ideas, es decir, respondían a la conformación de una ideología de unidad revolucionaria de la que tanto Ortega Peña, como Duhalde, Mario Hernández, Roberto Sinigaglia, Gustavo Roca (que venía mucho más del guevarismo-marxismo) formaban parte y eran sus reales mentores" (2015). De este modo, el proyecto político que había comenzado a expresarse a partir de "la Gremial" comenzó a aglutinar a buena parte de sus miembros en torno a Ortega Peña y Duhalde, dibujando los contornos del futuro grupo de MPL-DF. Entre ellos, podemos mencionar a Hernández, Galín, Sinigaglia, Zito Lema, González Gartland, Radrizzani Goñi y Roca. Todo ellos formaron parte del agrupamiento que luego, giró en torno al proyecto editorial de MPL-DF.

Para "la Gremial" en general y para los integrantes del grupo analizado en particular, una de las causas más importantes en la que intervinieron fue "la masacre de Trelew" sucedida el 22 de agosto de 1972. En esta última ciudad, habían quedado apresados 19 militantes, luego de haberse frustrado un plan de fuga con el que pretendían escapar de la cárcel de máxima seguridad, ubicada en Rawson y huir a Chile, en un avión secuestrado de la aerolínea Austral. El operativo había comprometido a las organizaciones más importantes del espectro revolucionario: FAR, PRT-ERP y Montoneros; en efecto, algunos de sus máximos dirigentes lograron escapar, cruzando la cordillera. ${ }^{28} \mathrm{El}$ resto quedó varado en el aeropuerto, dónde fueron nuevamente detenidos, tras pedir garantías jurídicas ante los principales medios de comunicación locales y nacionales. Tras conocer la noticia, una comitiva de abogados de "la Gremial" viajó a Trelew con la intención de tomar contacto con los detenidos. De la comitiva de letrados, casi todos fueron miembros del grupo que publicará MPL meses después: Ortega Peña, Duhalde, González Gartland, Galín y Radrizzani Goñi; la única excepción fue Mattarollo. ${ }^{29}$ La corta estadía en la ciudad sureña incluyó detenciones, amenazas y la explosión de una bomba luego de que el grupo intentara una conferencia de prensa para denunciar intimidaciones. Tras presentar recursos de habeas corpus para los y las detenidos/as y ver frustrado el objetivo de dialogar con ellos, volvieron a Buenos Aires. Ese mismo día, el 22 de agosto, los y las militantes fueron asesinados dejando un saldo de 16 muertes y tres sobrevivientes (Chama, 2010; Sartelli et al, 2009).

Rápidamente, "la masacre de Trelew" se transformó en un símbolo para la militancia revolucionaria. Para quienes conformaron el grupo cuya genealogía rastreamos aquí, la experiencia fue determinante no sólo por "la sangre derramada" sino por los niveles de unidad que demostraron las principales organizaciones armadas, marxistas y peronistas. En efecto, en una entrevista (auto) realizada y publicada en DF luego de que MPL fuera clausurada, Ortega Peña y Duhalde ponían sobre la mesa sus apuestas por la unidad revolucionaria y hacían explícitas las influencias de aquella experiencia:

Militancia siempre ha tratado de expresar las distintas manifestaciones del campo popular, tratando de cumplir un papel de confluencia entre los sectores militantes,

\footnotetext{
${ }^{28}$ Roberto Quieto y Marcos Osatinsky (FAR), Domingo Mena, Mario Roberto Santucho y Enrique Gorriarán Merlo (PRT-ERP) y Fernando Vaca Narvaja (Montoneros).

${ }^{29}$ Rodolfo Matarollo es el único caso que no puede considerarse parte del grupo político de MPL-DF. Aunque tuvieron un vínculo político estrecho, aquel se había acercado al PRT-ERP. En efecto durante la publicación de las revistas, Matarollo se desempeñó como director de Nuevo Hombre, publicación que desde 1972 había sido adquirida por la organización guevarista.
} 


\section{Mariela Stavale}

buscando ejes y posiciones que les son comunes y que constituyen en esencia, el proyecto de la Patria Socialista. La revista ha definido su posición desde la cual ha convocado a restablecer el "Frente de Trelew", no como un acuerdo superestructural entre dirigentes [...] sino como un frente de unidad en la lucha. (DF $n^{\circ} 1,02 / 05 / 1974, p$. 12)

La cita es relevante porque refleja los vínculos entre las improntas previas y las apuestas por la unidad en la acción del grupo MPL-DF: la estrategia frentista por la que bregaban encontraba su antecedente en el plan de fuga que había comprometido a peronistas y marxistas en torno a una causa común. Para el grupo, "Trelew" devolvía la posibilidad de la unidad en la coyuntura abierta por el gobierno peronista; unidad que buscaron replicar (y ampliar) hacia las organizaciones armadas y no armadas de la izquierda.

Es que esta mirada amplia venía atravesándolos desde los tempranos setenta. Los miembros del grupo tejieron relaciones con las FAR, las FAP, el PB y organizaciones ubicadas por fuera del espectro peronista como el PRT-ERP y los Comandos Populares de Liberación $(\mathrm{CPL})^{30}$. Efectivamente, sus miembros intensificaron los diálogos con dirigentes como Carlos Olmedo, Marcos Osatinsky, Pablo Cristiano, Roberto Quieto y Mario Roberto Santucho, entre otros. Además de la asesoría legal, los unía un debate continuo acerca de las estrategias y metodologías de actuación. Siguiendo a Rot destacamos la importancia de Alicia Euguren en estas discusiones. La viuda de Cooke también coincidió en que las diversas agrupaciones aún no habían dado en la clave de la organización revolucionaria (2016, p. 99).

Finalmente, otro de los frentes de militancia que se constituye como un antecedente clave para el grupo político analizado, fue la participación de sus miembros en la revista Nuevo Hombre en su primera época. Antes de adentrarnos en el análisis específico de este espacio de experiencia, interesa apuntar, de manera general, que aquella intensa sociabilidad política en torno de la defensa de presos políticos generó un compromiso que sobrepasó la actividad legal y que nutrió a muchas de las revistas que comenzaron a ser publicadas en esa época. De hecho, los futuros miembros de MPL habían participado de otras publicaciones en calidad de directores, integrantes de los equipos de redacción, asesores letrados o colaboradores externos. Ambas actividades (la intelectual y la jurídica) fueron conformando un "campo de denuncia" que se expresó, también, en estas publicaciones (Chama, 2010). La potencia que adquirió la confluencia entre ambos espacios no pasó desapercibida por las fuerzas de seguridad que, ya desde esta época, elaboraba informes de inteligencia sobre "la Gremial" y sobre los miembros del grupo MPL-DF. A modo de ejemplo, un "Parte de Inteligencia" confeccionado por la Secretaría de Informaciones del Estado (SIDE) y dirigido al General Etchepare -jefe del servicio de informaciones de la Pcia. de Buenos Aires- afirmaba:

A partir del 11/01/1972, las actividades de la "ASOCIACIÓN GREMIAL DE ABOGADOS" pasaron a adquirir progresivamente mayor gravitación [...] En líneas generales, su accionar hasta el presente estuvo orientado fundamentalmente a: a) Asumir $\underline{\text { la defensa de la totalidad de los elementos detenidos por actividades subversivas, }}$

\footnotetext{
30 Según Rot, los vínculos con FAR y los CPL fueron estrechos, aunque se vieron frustrados cuando ambas organizaciones decidieron integrarse a Montoneros. En su trabajo más reciente, González Canosa también hace referencia a este vínculo entre FAR y el grupo de abogados que luego integró el grupo MPL-DF (Rot, 2016, p. 99; González Canosa, 2021).
} 
afectados a las estructuras celulares de las organizaciones clandestinas "EJERCITO REVOLUCIONARIO DEL PUEBLO (ERP), "FUERZAS ARMADAS REVOLUCIONARIAS" (FAR), "FUERZAS ARMADAS PERONISTAS" (FAP), "FUERZAS ARMADAS DE LIBERACIÓN" (FAL) y "MONTONEROS"; b) Reunir testimonios sobre presuntos apremios ilegales y vehiculizar su difusión a través de conferencias de prensa, órganos periodísticos comprometidos ideológicamente (revistas "NUEVO HOMBRE", "PRIMERA PLANA", "AMERICA LATINA", etc.) [...] c) Facilitar asesoramiento a los elementos subversivos afectados a las distintas organizaciones armadas clandestinas. [El énfasis es nuestro] ${ }^{31}$

El informe de la SIDE destacaba las características que venimos señalando como claves de este proyecto político amplio, nutrido por la actividad defensista, la participación intelectual en revistas afines, la confluencia entre ambos espacios conformando "campos de denuncia" y las apuestas frentistas, de diálogo entre marxistas y peronistas. Todo ello hará eco en la revista MPL pero antes, también, en Nuevo Hombre (NH), que se establece como un antecedente importante por múltiples motivos.

La revista NH en su primera época (julio de 1971-enero de 1972) puede ser pensada como una experiencia "singular y bisagra" por las confluencias que allí se produjeron y los debates a los que dio lugar (Abbatista, 2014, p. 3). En efecto, como adelantamos, esta experiencia editorial adquiere una importancia capital, no sólo porque expresó un "campo de denuncia" a partir de la publicación de secciones específicas orientadas a develar el sistema represivo de la dictadura sino, especialmente, porque, al decir de Zito Lema, "allí participamos todos los futuros miembros de MPL" (2015). En efecto, entre los primeros convocados por su director, Enrique Walker, ${ }^{32}$ podemos mencionar a Ortega Peña, Duhalde, Euguren, Zito Lema y Sinigaglia; también a Nicolás Casullo (Baschetti, 2015, p. 25).

Los futuros integrantes de MPL-DF cumplieron diversas tareas en NH: Zito Lema estaba a cargo de la sección "Cultura y Cuestionamiento"; Ortega, Duhalde, y Euguren pertenecían al equipo de redacción y Sinigaglia aportaba con testimonios específicos acerca de los significados de la actividad defensista. La idea del proyecto político-editorial había sido publicar un semanario que tuviera una buena producción de notas y artículos que reunieran denuncia y proyecto político de liberación, desde una perspectiva ideológicamente amplia y directa (Anguita y Caparrós, 2006, p. 238). En efecto, siguiendo a Martín Santanna observamos que uno de los pilares del proyecto fue su amplitud,

La revista no es expresión de ninguna tendencia en particular ni tiene un sesgo ideológico definido. NH apoya todas las expresiones de resistencia -desde la lucha armada hasta el sindicalismo combativo- y promueve la confluencia entre marxistas y peronistas frente a los enemigos en común: la dictadura, la derecha y la dirigencia sindical. (2015, p. 12)

\footnotetext{
${ }^{31}$ Legajo $\mathrm{N}^{\circ}$ 526, Asunto: “Asociación Gremial de Abogados - Foro de Buenos Aires por la vigencia de los derechos humanos. Su origen y vinculación con organizaciones extremistas 'F.A.L.' 'F.A.P.' 'E.R.P.' y 'Montoneros'”, Carpeta Varios, Mesa DS, Archivo DIPBA, Comisión Provincial por la Memoria, La Plata.

${ }^{32}$ Es interesante acotar que Enrique Walker fue, luego, el director de la revista: El Descamisado; órgano oficial de la organización Montoneros, coetánea a la revista MPL. En efecto, la publicación fue un interlocutor clave para el grupo aquí analizado, durante los años 1973-1974.
} 


\section{Mariela Stavale}

Estas características se replicaron luego en la experiencia de las revistas que son objeto de nuestra indagación. Efectivamente, las coincidencias no se reducen sólo a similitudes editoriales o a la participación efectiva de muchos de los futuros miembros del grupo analizado, sino también al hecho de que sus páginas abonaron de manera temprana a la conformación de un proyecto amplio que MPL y DF expresaron tiempo después: ambas experiencias editoriales -sin ser partidarias- fueron "fruto y parte de una política frentista en la que confluían diferentes sectores del campo popular" (De la fuente, 2015, p. 29).

La participación de los futuros miembros del grupo MPL-DF en NH abonó a la conformación de aquel "campo de denuncia" en las publicaciones revolucionarias. Como dijimos, Sinigaglia aportaba esporádicamente con testimonios acerca del significado de defender presos políticos. Por su parte, Ortega Peña y Duhalde, escribieron dos secciones constantes: "Informe sobre opresores" y "El peronismo y la guerra". A través de ambas, buscaron develar "los abusos del Sistema": las acusaciones enfatizaban en el accionar represivo y policial por un lado y los procedimientos judiciales, por el otro. Siguiendo a Rot, es posible observar que ambos analizaban "el conjunto del sistema judicial-penal-militar" e identificaban "un sistema represivo dónde lo legal y lo clandestino interactúan en creciente reciprocidad (Rot, 2015, p. 37).

A la vez, en la sección "El peronismo y la guerra", el dueto vertió sus ideas-fuerza sobre el vínculo peronismo-revolución. En efecto, allí caracterizaron a la Argentina como un "país semi-colonial" (identificando al nosotros revolucionario y a "los enemigos") y al peronismo como un "movimiento de resistencia" $\left(\mathrm{NH} \mathrm{n}{ }^{\circ} 21,12 / 1971, p\right.$. 5). Siguiendo a Rot, este tipo de definiciones no implicaba afirmar que el peronismo era revolucionario, sino que "debía superarse a sí mismo y convertirse en tal" (2016, p. 97). En otros términos, podríamos afirmar que el movimiento era valorado como "identidad política" por contener aquellos elementos de la conciencia obrera que, de ser radicalizados, podían conducir al socialismo. ${ }^{33}$ En esta lectura, el movimiento peronista implicaba el mayor nivel de conciencia al que había llegado el proletariado. Siguiendo a James, observamos que, en efecto, la clave para entender estas reinterpretaciones se vincula a la experiencia resistente de los trabajadores: durante los años de proscripción, aquellos habían trastocado "sus estructuras de sentimiento, penetrándolas de resonancias de clase y estableciendo el tono de las relaciones políticas y sociales para toda una generación de peronistas de las clases" (2010, p. 135)

Lo cierto es que esta caracterización del peronismo como nivel de conciencia obrera, será un eje central para entender los posicionamientos de MPL-DF y las transformaciones que esas interpretaciones suscitaron en la identidad política del grupo que las publicó en una coyuntura completamente diferente: la del tercer gobierno peronista, en 1973.

\footnotetext{
${ }^{33}$ González Canosa realiza un análisis similar del posicionamiento que las FAR venían asumiendo en su proceso de peronización. Este paralelismo expresa, por un lado, la cercanía política entre los integrantes del futuro grupo de MPL y la organización armada y, en consecuencia, coincidencias en la caracterización del rol del movimiento y de Perón. Siguiendo a la autora, las FAR caracterizaba a Perón como un "líder popular" (no revolucionario) y caracterizaba la relación líder/masas como una "primera etapa (...) cuando el nivel de conciencia no había podido producir, aún, la herramienta político-militar” (2018, p.: 179 y 2021).
} 


\section{Mariela Stavale}

\section{Es tiempo de Militancia, "desde abajo y por el frente". Las revistas MPL-DF, un recorrido general}

El objeto de indagación de este artículo han sido los espacios de experiencia previos y compartidos por quienes, luego, conformaron el grupo MPL-DF. Sin embargo, consideramos necesario acercar un recorrido general sobre esta experiencia político editorial, para iluminar la forma en que las ideas-fuerza que fuimos marcando como claves del período previo, reaparecen como huellas que surcan las posiciones de las revistas, durante la coyuntura de su publicación.

En términos generales, MPL y DF expresaron mutaciones identitarias que pueden analizarse a partir de diferentes tópicos político-ideológicos que, en la época, también resultaron decisivos para el resto de los actores del peronismo revolucionario. A saber: la forma de pensar la contradicción principal, el sujeto revolucionario y el objetivo final de la transformación social; la caracterización del movimiento peronista, sus sectores internos y el rol de Perón y las estrategias para impulsar ese proceso. ${ }^{34}$ Las definiciones alrededor de estos ejes fueron claves para comprender el posicionamiento de la revista frente a la exasperación de la coyuntura política en torno a cuestiones clave como la experiencia del tercer gobierno peronista, el debate hacia dentro del peronismo de izquierda (principalmente, con Montoneros-JP) y, también, con el resto de los actores del campo revolucionario. En efecto, el análisis de las posiciones de MPL y de DF arroja luz sobre la centralidad del conflicto para explicar las identidades políticas (Gimenez, 2007); el enfrentamiento creciente entre el grupo y la experiencia del tercer peronismo es clave para explicar las variabilidades de su identidad peronista: sus metamorfosis y nuevas suturas, fueron forjándose al calor de las disputas políticas, en una coyuntura violentamente adversa.

Al igual que gran parte de la izquierda peronista, el grupo político inició cargando de expectativas revolucionarias el retorno del peronismo al poder, pero terminó enfrentándose con la experiencia del gobierno peronista. La particularidad de MPL-DF (y en general, del resto de los actores de la constelación alternativista) radicó en que ese enfrentamiento se tornó explícito y significó una ruptura con el liderazgo de Perón sin que ello implique abandonar al peronismo como identidad política (Stavale, 2018; 2021). En ese movimiento, el grupo político acentuó el carácter clasista de sus planteos, izquierdizando su peronismo.

En este punto, es posible realizar una periodización en el análisis de las publicaciones, identificando diferentes momentos que fueron marcando el proceso de transformación de la identidad del agrupamiento. El primero de ellos coincidió con la "primavera camporista" y fue el tiempo de las "expectativas revolucionarias": en términos generales, esta breve experiencia había generado ilusión en amplios sectores sociales y el grupo MPL-DF estuvo lejos de ser una excepción. Sin embargo, la experiencia terminó de manera abrupta tras la renuncia del presidente a tan sólo un mes y medio de haber asumido - con la "masacre de Ezeiza" como telón de fondo. ${ }^{35}$

\footnotetext{
34 También, en un artículo reciente junto a Mora González Canosa, analizamos la forma en que estos tópicos político-ideológicos operaron el posicionamiento de las organizaciones armadas peronistas más importantes: Montoneros, Descamisados, Fuerzas Armadas Revolucionarias y Fuerzas Armadas Peronistas. La intención fue trazar coordenadas que permitan plantear una cartografía comparativa, con el objetivo de aportar matices y complejidad al campo de estudios del peronismo revolucionario (2021)

${ }^{35} \mathrm{La}$ renuncia de Cámpora fue otro duro golpe para los diversos sectores nucleados en torno a la TRP. Las interpretaciones al respecto también variaron. La posición pública de Montoneros y JP fue la de considerar la renuncia como una expresión de lealtad a Perón, asimilándolo al "renunciamiento heroico" de Evita (El Descamisado (ED) $N^{\circ}$, 17/07/1973: 2). Del lado alternativista, en cambio, se sostuvieron posiciones más duras
} 
De manera interina hasta celebrar nuevas elecciones, la gestión quedó a cargo de Lastiri; bajo su interinato y con el guiño de Perón -quien regresó al país y se despojó de la ambigüedad que había caracterizado sus posiciones durante el exilio, en detrimento de la izquierda en general y la peronista en particular (Svampa, 2003, p. 391), comenzó la "limpieza" de los sectores considerados "subversivos" y "marxistas" al interior del peronismo, así como el endurecimiento progresivo de las políticas de seguridad a nivel nacional (Franco, 2012).

Este período puede pensarse como un momento "liminal" en la identidad política del grupo MPL-DF (Castillejo Cuellar, 2017). Es decir, una fase intermedia (y contradictoria), en dónde las expectativas revolucionarias que había logrado generar el gobierno de Cámpora se disiparon rápidamente, dando lugar a posicionamientos profundamente críticos respecto del gobierno y del rol de Perón. En esta nueva coyuntura, el grupo político asumió expresamente las posiciones alternativistas, que reverdecían como posibilidad política frente a "la trampa" que significaba ser peronistas, pero enfrentar a Perón (Sigal y Verón, 2003). Las páginas de MPL comenzaron a denunciar una fractura irreconciliable al interior del movimiento -entre un peronismo "de arriba", "burocrático y burgués" y otro de las bases- que ahora se tornaba evidente. La apuesta reforzaba la necesidad de construir la organización independiente de la clase obrera peronista y se hacía eco de las viejas lecturas de Cooke quien, como vimos, llamaba a "hacer bullir" al peronismo de las bases desde los tempranos sesenta.

Finalmente, las posiciones respecto del liderazgo del viejo caudillo oscilaron entre un "apoyo condicionado" 36 y cuestionamientos cada vez más explícitos que, más temprano que tarde, sobre todo tras su asunción a la presidencia el 12 de octubre de 1973, se transformaron en un enfrentamiento abierto. Si hasta ese momento, la referencia al liderazgo de Perón y su vínculo con la clase obrera se sostuvieron a partir de una relación que subrayaba una necesidad mutua: "no hay peronismo sin Perón pero tampoco Perón sin peronismo" (MPL n 9, 09/08/1973, p. 3) -lo que suponía que el liderazgo del viejo caudillo dependía de la representación de los intereses "reales" (y socialistas) de la clase obrera-, la nueva etapa resolvía el dilema en detrimento de Perón: abortando la primera parte de la frase y apostando por la posibilidad de un "peronismo sin Perón". Además, La última etapa de MPL expresó otras transformaciones puntuales: si hasta el momento la revista había utilizado las categorías de "pueblo" y "clase" como sinónimos para referirse al sujeto revolucionario, los planteos de esta etapa acentuaron su carácter clasista, haciendo pie en el rol de la clase obrera. A su vez, MPL comenzó a centrarse en la contradicción "burguesía-proletariado" para caracterizar el proceso revolucionario, explicitando que entre capitalismo y socialismo no existía "tercera posición". Finalmente, el grupo político remplazó la referencia al "socialismo nacional" por el "socialismo" a secas, en un movimiento que expresó la radicalización de la identidad política del grupo (Stavale, 2018). ${ }^{37}$

que entreveían una renuncia forzada o denunciaban, directamente, un "golpe palaciego", "orquestado" por "el enemigo interno" (Stavale, 2018).

${ }^{36}$ Con esta expresión hacemos referencia a los condicionamientos reales que se sobreponían al apoyo que el grupo político sobreponían a la candidatura de Perón. A modo de ejemplo, afirmaban que Perón debía ser presidente, pero para corregir el proceso en marcha (es decir, el giro a la derecha que había supuesto el interinato de Lastiri) o que su liderazgo dependía de encarna los intereses "reales" (socialistas) de los trabajadores, o "dejaría de ser Perón". Este apoyo a medias caracterizó, también, al resto de los actores alternativistas y se resquebrajó dos días después de la victoria electoral de Perón, sobre todo tras el avance represivo que desató la muerte de Rucci (Stavale, 2018; 2021)

${ }^{37}$ Respecto del gobierno de Perón, MPL fue expresamente crítica. A modo de ejemplo, desde sus páginas, denunciaron su carácter contrarrevolucionario reflejado en políticas concretas como la modificación a la ley de Asociaciones Profesionales aprobada a fines de 1973, la reforma al Código Penal de enero de 1974 o el avance de 
Sin embargo, a pesar de que, durante todo el proceso, las rupturas fueron frondosas, una continuidad debe destacarse: aún con los niveles de beligerancia alcanzados respecto de Perón y el movimiento peronista, MPL se mantuvo dentro de los límites del peronismo, esforzándose por expandir su enfoque. La revista reclamó "el peronismo de los trabajadores", dislocándolo de Perón y de la experiencia de su gobierno. Esta estrategia política podría interpretarse bajo la lupa de lo que Sigal denomina "operaciones ideológicas", en su análisis del acercamiento de la izquierda marxista al peronismo en los tempranos sesenta. Una de esas estrategias fue "escotomizar ${ }^{38}$ el papel de Perón", separando al peronismo de su jefe (2002). ${ }^{39}$

A su vez, la opción por el "peronismo sin Perón" había sido esgrimida por el sindicalismo vandorista que, aunque lejos del marxismo, buscó independizarse de Perón a partir de la creación de un partido de corte laborista y corporativo, sustentado en el poder de los sindicatos. Considerando estos elementos, resulta difícil obviar las filiaciones de los dirigentes del grupo político que, en los tempranos sesenta, se aceraron al peronismo desde el marxismo nacional e incluso apostaron por la construcción política con todos los actores del Movimiento Peronista, incluyendo a la CGT de Vandor. Podríamos decir, cuanto menos, que la apuesta del "peronismo sin Perón" era una estrategia conocida por Ortega Peña y Duhalde, re-significada ahora en favor de la autonomía revolucionaria de la clase obrera peronista.

En su última etapa, MPL y DF hicieron especial énfasis en dos apuestas políticas; la primera ya mencionada, fue la contraposición de dos peronismos: el "de arriba" burocrático y burgués (y ahora también asociado a Perón) y el "peronismo de abajo" o "verdadero" 40 (Altamirano, 2001), vinculado a la experiencia de una clase obrera, revolucionaria y peronista. Esta línea de interpretación se ligó a la apuesta por construir una alternativa independiente, para y de la clase obrera y se potenció luego de la clausura de MPL en marzo de 1974. En efecto, la revista DF condensó las transformaciones político-ideológicas de la identidad del grupo político, que se expresaron, incluso, en la elección del nombre de la nueva publicación. Bajo el título "De Frente", la reivindicación a Cooke fue directa (puesto que se filiaba con el periódico que, con el mismo nombre, fue publicado por el líder peronista durante "la resistencia") y se estableció como una referencia política del movimiento peronista, que desplazó la figura de Perón. Por otra parte, la mención a las bases peronistas -es decir, a la experiencia política de la clase obrera en y a través del peronismo- constituyó el único vínculo entre la identidad política del grupo y el movimiento popular.

la depuración política en provincias afines a la izquierda peronista, que produjeron la renuncia de gobernadores como Bidegain en Buenos Aires u Obregón Cano en Córdoba (Servetto, 2010). El avance de la represión legal y extralegal llevó a que MPL le endilgara el mote de "gorila" al propio Perón o encerrara a sus ministros en la sección La cárcel del pueblo, sugiriendo que el propio líder peronista tenía un lugar en la celda editorial (para más información sobre las revistas ver: Stavale, 2018).

${ }^{38} \mathrm{La}$ autora utiliza este término, que proviene del psicoanálisis y se usa para describir una suerte de "ceguera inconsciente" a partir de la cual, los sujetos obvian u olvidan los hechos desagradables de su conciencia o memoria.

${ }^{39}$ Sigal apunta que los sectores de izquierda durante la década del 60, se "peronizaron" a partir de dos operaciones ideológicas relevantes: la primera, referida a la escisión entre "identidad de clase" e "identidad política": si el peronismo era la identidad política de los trabajadores, debían "evolucionar" hacia la primera. La segunda operación es la que aquí hemos referido (2002, pp. 177-179).

${ }^{40}$ Altamirano distingue el "peronismo verdadero" del "empírico". El primero es definido como una experiencia real que cuando se le atribuía a los trabajadores, no podía extenderse a los dirigentes políticos o sindicales, quienes forman parte del "peronismo empírico". Allí también puede incluirse al propio Perón, quien no siempre representó la verdad del peronismo. Cuando esto sucedió, el evocador fue la clase obrera (2001, pp. 130-134) 
Este es un punto interesante que, además, explica una continuidad (entre las múltiples rupturas) en la identidad peronista del grupo: si antes afirmamos que el agrupamiento puso en juego una estrategia similar a la segunda "operación ideológica" señalada por Sigal al separar al peronismo de Perón, no podemos decir lo mismo respecto de la primera de esas operaciones: la escisión entre identidad de clase e identidad política. Para el grupo de MPL-DF, la clase obrera se constituyó como tal en y con su identidad política; es decir la identidad peronista no venía después como añadido inesencial, sino que era parte de la experiencia de clase de los trabajadores.

Finalmente, la segunda apuesta política interpeló al resto de los actores revolucionarios, peronistas y marxistas. Hacia dentro del peronismo revolucionario, MPL y DF discutieron fundamentalmente con Montoneros y JP, por ser las organizaciones hegemónicas del espectro. Aunque las coincidencias no estuvieron a la orden del día -pues el grupo criticaba sus posiciones políticas cuestionando su movimientismo y la poca disposición de enfrentar explícitamente a Perón ${ }^{41}$ - nunca dejó de interpelarlos. Las revistas MPL-DF apelaron a la construcción de un "frente revolucionario" -que denominaron el "Frente de Trelew"- en el que confluyeran amplios sectores del campo popular. Esta apuesta potenció la propuesta de una alternativa independiente puesto que, para el grupo político, el proceso revolucionario debía sostenerse en y desde la experiencia de la clase obrera peronista. A la vez, allanó el diálogo con organizaciones marxistas como el PRT-ERP, que venían apelando a construir espacios políticos comunes con el peronismo revolucionario (Stavale y Stavale, 2021).

A partir de este tipo de apuestas, el grupo replicaba un ideario político que los había caracterizado desde el comienzo y en espacios previos: la afirmación de que todas las organizaciones que enfrentaban al sistema formaban parte del campo popular. En la coyuntura de 1974, esta afirmación re-significó el vínculo gestado con los sectores de la izquierda no peronista, supeditando las diferencias que podían separarlos a la condición de "contradicciones secundarias y no antagónicas". Según el grupo MPL-DF, la urgencia política del presente requería de la unidad del campo revolucionario, sintetizando su práctica política a través de un frente de liberación con hegemonía de los trabajadores ( $\mathrm{DF} \mathrm{n}^{\circ} 3,16 / 05 / 1974$, p. 23). En efecto, el grupo político terminó integrándose al Frente Antiimperialista y por el Socialismo (FAS), iniciativa impulsada por el PRT-ERP y otros sectores de la constelación alternativista, como el Frente Revolucionario Peronista (FRP) dirigido por Jaime y Euguren. Sin embargo, el rol que el grupo buscaba forjar dentro y fuera del peronismo revolucionario se vio interrumpido abruptamente por el asesinato de Ortega Peña por parte de la organización paraestatal Alianza Anticomunista Argentina (AAA), el 31 de Julio de 1974. Su muerte significó, también, el final de la experiencia político-editorial del grupo político. Parafraseando a Rot, diremos que, tal vez impulsados por el dolor de la pérdida y tras los vaivenes del itinerario que hemos trazado, muchos de quienes hicieron MPL y DF concibieron una nueva organización que amputó al peronismo de la

${ }^{41}$ El 1 de mayo de 1974, con motivo de celebrar el día del trabajador, sectores del peronismo revolucionario hegemonizados por Montoneros y JPr asistieron a un acto en Plaza de Mayo. Esa jornada devino histórica y simbolizó el enfrentamiento público entre la organización hegemónica de la izquierda peronista y el Perón. Los actores de la constelación alternativista no asistieron al acto. Sin embargo, el grupo político MPL-DF subrayó en la revista DF que consideraba positivo que Montoneros definiera "un enfrentamiento con este proyecto [...] a través de sus consignas y con el abandono masivo de la plaza". Como una forma de propiciar un debate ideológico con la conducción de la organización, la revista alertaba que tras estos hechos no podían "volver atrás" ni intentar "volver a conciliar" con Perón pues hacerlo, implicaría "pasar al campo del enemigo" (Stavale, 2018, p. 243; Stavale, 2018b). 


\section{Mariela Stavale}

definición de su identidad política: el Partido Revolucionario de los Obreros Argentinos (PROA), que se definió marxista-leninista, ya sin intenciones de adscribirse al movimiento peronista (2016, p. 120). Pero ese ya es un capítulo de otra historia.

\section{Algunas reflexiones finales}

A lo largo de este artículo, nos propusimos abordar la experiencia del grupo político que publicó las revistas MPL-DF, entre 1973-1974. Nuestra intención no fue concentrarnos específicamente en las publicaciones sino, más bien, en los desafíos teórico-metodológicos de "hacer devenir" a las revistas como objeto de estudio. A la vez, colocadas en la perspectiva de la nueva izquierda, nos interesó detenernos, sobre todo, en uno de los movimientos que el enfoque habilita: aquel que invita a "mirar hacia atrás", volviendo a los orígenes del ciclo y a las trayectorias de los itinerarios que aquí estudiamos.

Como hemos dicho, una estrategia clave para analizar la experiencia editorial de MPL-DF fue abordarlas a partir de la noción de grupo político. El concepto habilitó a reconstruir los itinerarios previos de sus miembros para analizar cómo se fue gestando el proyecto político que MPL-DF expresó y desarrolló. Al decir de Kosellek, fue la tensión entre estos "espacios de experiencia" y el "horizonte de expectativas" del grupo político, lo que nos permitió ir reconstruyendo el decir de las revistas: sus apuestas políticas y su variabilidad en el tiempo (1993). En segundo lugar, porque, como hemos buscado evidenciar, ni MPL ni DF pueden reducirse a un análisis del discurso o a la reconstrucción de tareas de producción y circulación: ambas aglutinaron a actores políticos diversos que se acercaron al espacio político-editorial identificados con las ideas y apuestas que allí se generaron. Finalmente, retomando a Lenin, podemos apuntar que las revistas cumplieron el rol de "organizador colectivo" aunque para un grupo político que no formó parte de una estructura partidaria. En este punto, MPL-DF fueron, al mismo tiempo, una usina de ideas y un actor político: la primera, porque las revistas generaron un espacio de sociabilidad militante que las fue nutriendo del debate político que atravesó al campo revolucionario; la segunda, porque MPL-DF no fueron tan solo un reflejo de esas ideas, sino que las transformaron en apuestas concretas con pretensiones hegemónicas para el campo revolucionario, peronista y marxista.

Otra dimensión señalada, fue analizar la experiencia MPL-DF considerándolas, al mismo tiempo, como un punto de llegada y de partida para el grupo político que giró en torno a ellas. Este abordaje, permitió reconstruir los itinerarios previos de quienes confluyeron en MPL, para iluminar la idea de que la revista puede entenderse como un punto de llegada en la experiencia de sus integrantes; aquella dinámica señalada por Gramsci, en torno a las orientaciones generales, las premisas y los fines del agrupamiento. Sin perder de vista que las revistas político-culturales conservan las pruebas de cómo se pensaba el futuro desde el pasado (Sarlo, 1992), buscamos visibilizar que algunas ideas-fuerza fueron punteando la trayectoria militante de los integrantes del grupo y se refractaron luego, como "experiencia articulada" en el decir de las revistas (Williams, 2001, p: 20). Para nombrar algunas de ellas, el vínculo entre liberación nacionalrevolución social y el rol de un marxismo nacional "situado en el lugar de la teoría", la preocupación por la autonomía política de la clase obrera peronista o la apuesta por la unidad revolucionaria, fueron inquietudes que delinearon el itinerario político de Ortega Peña y Duhalde 


\section{Mariela Stavale}

-los dirigentes del grupo- y también del resto de sus integrantes con quienes convergieron en espacios de experiencia previos como "la Gremial" o la revista Nuevo Hombre.

\section{Bibliografía}

Abbatista, L. (2014) "La primera época de la revista Nuevo Hombre y sus aportes al debate sobre los intelectuales revolucionarios. Argentina, 1971”. II ${ }^{\circ}$ Congreso de Historia Intelectual de América Latina.

Altamirano, C. (2001). Peronismo y cultura de izquierda. Buenos Aires: Siglo XXI.

Anguita, E. y Caparrós, M. (2006) La Voluntad. Una historia de la militancia revolucionaria en la Argentina. Buenos Aires: Edición Booket.

Balvé, B. (1989) El 69: huelga política de masas. Rosariazo/ Cordobazo/ Rosariazo. Buenos Aires: Contrapunto, 1989.

Barletta A. y Lenci L. (2001) "Politización de las Ciencias Sociales en la Argentina. Incidencia de la revista Antropología 3er. Mundo 1968-1973", Sociohistórica, Cuadernos del CISH $\mathrm{n}^{\circ} 8$, pp. 177-199.

Barth, F. (1976) Los grupos étnicos y sus fronteras. La organización social de las diferencias culturales. México: Fondo de Cultura Económica.

Baschetti, R. "Del nuevo hombre a Nuevo Hombre. Resistencia y dignidad siempre". En: Colección reediciones y antologías Biblioteca Nacional (2015) Nuevo Hombre, Edición Facsimilar, Buenos Aires: Biblioteca Nacional.

Besoky, J. L., (2016) "La derecha peronista. Prácticas políticas y representaciones (1943-1976)”, Tesis de Doctorado en Ciencias Sociales, Universidad Nacional de La Plata. . (2019) "Cultura e identidad política en el peronismo de derecha", Historiae Vol.9(2), p.: 93-111.

Bozza, J.C. (2009). "La voluntad organizada. La CGT de los Argentinos: una experiencia de radicalización sindical”, en: Anuario del Instituto de Historia Argentina n9, pp.: 179208

. (2014) "La resignificación revolucionaria del peronismo revolucionario y sus protagonistas durante la etapa de la proscripción”. En: Tortti, M.C. (Dir.) La nueva izquierda argentina (1955-1976). Socialismo, peronismo y revolución. Rosario: Prohistoria, pp.: 59-82.

Brennan J. y Gordillo M. (2008). Cordobazo, clasismo y movilización social. La Plata: de la Campana

Campos, E. (2016). Cristianismo y Revolución. El origen de Montoneros. Violencia política y religión en los '60, Buenos Aires: Edhasa.

Castillejo Cuellar, A. (2017). (2017) La ilusión de la justicia transicional: perspectivas críticas desde América Latina y Sudáfrica, Colombia: Editorial Universidad de los Andes, Colombia.

Celecia F. y Waisberg, P. (2007). La ley y las armas. Biografía de Rodolfo Ortega Peña. Buenos Aires: Editorial Aguilar. 


\section{Mariela Stavale}

Chama, M. (2010). "La defensa de los presos políticos a comienzos de los 70': ejercicio profesional, derecho y política". En Cuadernos de Antropología Social Vol 32 (32), pp.: 195-217.

Cullen R. (2008). Clase obrera, lucha armada, peronismos. Génesis, desarrollo, crisis del peronismo original, La Plata: de la Campana.

De la fuente, V. (2015). “'Desde abajo y por el frente'. Nuevo Hombre bajo la dirección de Silvio Frondizi”, en: Colección reediciones y antologías Biblioteca Nacional (2015) Nuevo Hombre, Edición Facsimilar, Buenos Aires: Biblioteca Nacional.

Duhalde E. L. y Pérez, E. (2003) De Taco Ralo a la alternativa independiente. Historia documental de las Fuerzas Armadas Peronistas y el Peronismo de Base, La Plata: de la Campana.

Eidelman, A. (2004). Militancia e historia en el peronismo revolucionario de los años 60: Ortega Peña y Duhalde. Buenos Aires: Editorial Centro Cultural de la Cooperación.

Franco, M. (2012). Un enemigo para la Nación. Orden interno, violencia y “subversión”, 19731976. Buenos Aires: Fondo de Cultura Económica.

Gasparini, J. (2006). Manuscrito de un desaparecido en la ESMA. El libro de Jorge Caffatti, Buenos Aires: Grupo Editorial Norma.

Gillespie, R. (2008). Soldados de Perón. Historia crítica sobre los Montoneros. Buenos Aires: Editorial Sudamericana.

Gimenez, G. (2007) Estudios sobre la cultura y las identidades sociales. México: CONACULTA e Instituto Tecnológico y de Estudios Superiores de Occidente.

González Canosa, M. (2021). Los futuros del pasado. Marxismo, peronismo y revolución, una historia de las FAR. Buenos Aires: Prometeo.

González Canosa, M. y Stavale, M. "Peronismo, izquierda y lucha armada. Balance bibliográfico y perspectivas analíticas sobre las organizaciones armadas peronistas en clave comparada”. En: Páginas (Rosario): Revista Digital de la Escuela de Historia Vol. 13(31), pp.: 1-31.

Gramsci, A. (2012). Los intelectuales y la organización de la cultura. Buenos Aires: Nueva Visión.

Gurrucharri E, Perez J, Fontana E y Alfaro S. (2020). La patria socialista. Una historia de la corriente del peronismo revolucionario, MRP, JRP, MR17, FR17. Buenos Aires: Ediciones En Lucha.

James, D. (2010) Resistencia e integración. El peronismo y la clase trabajadora argentina, Buenos Aires: Editorial Siglo XXI.

Koselleck, R. (1993). "Espacio de experiencia y horizonte de expectativa, dos categorías históricas”. En: Futuro pasado. Para una semántica de los tiempos históricos. Barcelona: Paidós, pp.: 333-357

Ladioux, J. (2005). "La mazorca de Perón: prácticas ideológicas de la derecha peronista. Una aproximación a partir de un estudio de caso. Mar del Plata 1970-1976”. En: X Jornadas Interescuelas/Departamentos de Historia. (2021). "Sindicatos, Partido, Universidad y Poder Judicial: El papel de las derechas peronistas en la configuración de un complejo contrainsurgente. Mar del Plata 19701976". En: Cuadernos de Marte (21), 97-128.

Lanusse, L. (2005). Montoneros. El mito de sus doce fundadores. Buenos Aires: Editorial Vergara. 


\section{Mariela Stavale}

Laufer, R. (2021). "El sindicalismo clasista en la Argentina del Cordobazo. Estrategias sindicales y radicalización política en el SMATA Córdoba, 1966-1972", Tesis de Doctorado en Historia, Universidad Nacional de Buenos Aires.

Lenci, M.L. (1999), “Cámpora al gobierno, Perón al poder. La tendencia revolucionaria del peronismo ante las elecciones del 11 de Marzo de 1973” En: Pucciarelli, A. (Ed.) La primacía de la política. Lanusse, Perón y la Nueva Izquierda en tiempos del GAN, Buenos Aires: Eudeba.

Luvecce, C. (1992) Las Fuerzas Armadas Peronistas y el Peronismo de Base. Buenos Aires: Ediciones CEAL.

Pastoriza, E. (2011) "Escribir historia política, escribir historia. Entrevista con Juan Carlos Torre". En: PolHis n 8, pp.: 241-245

Pluet-Despatin, J. (1999) "Contribución a la Historia de los Intelectuales. Las revistas" (traducción de Horacio Tarcus; revisión técnica de Margarita Merbilhaá)” En: AMÉRICALEE. El portal de publicaciones latinoamericanas del siglo XX.

Pozzi, P. y Schbeider, A. (2000). Los setentistas. Izquierda y clase obrera: 1969-1976, Buenos Aires: Eudeba.

Raimundo, M. (2004). "Izquierda peronista, clase obrera y violencia armada: Una experiencia alternativa" En: Sociohistórica n¹5-16, pp.: 99-128.

Robertini C. (2020). "Hemos sido férreos combatientes de la subversión. Historia oral de un sindicalista de la derecha peronista durante los años 70”. En: Nuevo Mundo Mundos Nuevos.

Rot, G. (2015). “La justicia es política... y la Guerra también. Eduardo Luis Duhalde y Rodolfo Ortega Peña en Nuevo Hombre". En: Colección reediciones y antologías Biblioteca Nacional. Nuevo Hombre, Edición Facsimilar, Buenos Aires: Biblioteca Nacional, pp.: $37-41$.

(2016) Itinerarios revolucionarios. Eduardo L. Duhalde y Haroldo Loguiurato. De la Resistencia Peronista al Partido Revolucionario de los Obreros Argentinos. La Plata: Editorial de la Campana.

Santanna M. (2015). "Nuevo Hombre: una revista como síntesis de una época”. En: Colección reediciones y antologías Biblioteca Nacional. Nuevo Hombre, Edición Facsimilar, Buenos Aires: Biblioteca Nacional, pp.: 11-19.

Sarlo, B. (1992). "Intelectuales y revistas: razones de una práctica". En: América: Cahiers du CRICCAL n9-10, pp. 9-16. (2001) La batalla de las ideas (1943-1973), Editorial Ariel, Buenos Aires.

Sartelli E., Grenat S. y Lopez Rodriguez, R. (2009). Trelew, el informe. Arte, ciencia y lucha de clases: 1972 y después. Buenos Aires: Editorial Razón y Revolución.

Seminara, L. (2015). Bajo la sombra del ombú. Montoneros Sabino Navarro, historia de una disidencia, Buenos Aires: Imago Mundi.

Servetto, A. (2010). 73/76. El gobierno peronista contra las "provincias montoneras", Buenos Aires: Editorial Siglo XXI.

Sigal, S. (2002. Intelectuales y poder en Argentina. La década del sesenta, Buenos Aires: Editorial Siglo XXI.

Sigal, S. y Verón, E. (2003). Perón o muerte. Los fundamentos discursivos del fenómeno peronista. Buenos Aires: Legasa.

Sorín, D. (2014). John William Cooke, la mano izquierda de Perón. Buenos Aires: Grupo Planeta. 


\section{Mariela Stavale}

Stavale, M. (2012) "Las Fuerzas Armadas Peronistas y su experiencia alternativa (1964-1979)". Tesina de Grado en Licenciatura en Sociología, Universidad Nacional de La Plata. (2018) "Las revistas Militancia Peronista para la Liberación y De Frente, con las bases peronistas: una propuesta alternativa para la identidad política del peronismo revolucionario, 1973-1974". Tesis de Doctorado en Ciencias Sociales, Universidad Nacional de La Plata. (2018b) "La revista De Frente, con las bases peronistas. Una experiencia alternativa para el peronismo revolucionario”, En: Conflicto Social Vol 11 (20), pp.: 92-123. (2021) "El peronismo es de los trabajadores. La corriente alternativista del peronismo revolucionario durante el tercer gobierno de Perón”. En: Tortti, M.C. y González Canosa, M (Dir.) La nueva izquierda en la historia reciente argentina. Debates conceptuales y análisis de experiencias, Rosario: Prohistoria [En prensa], pp.: 223-254.

Stavale, M. y Stavale S. (2021) "Peronistas y marxistas por la patria socialista: un análisis comparativo del PRT-ERP y el PB ante el tercer gobierno peronista". En: Anuarios del IDHES. [En prensa].

Svampa, M (2003), “El populismo imposible y sus actores, 1973-1976”. En: James, D. (Dir.) Nueva historia argentina, Buenos Aires: Sudamericana.

Tocho, F. (2020). "Lógicas políticas en tensión: la Tendencia Revolucionaria del Peronismo y su participación en el gobierno constitucional de la provincia de Buenos Aires (19731974)", Tesis de Doctorado en Historia, Universidad Nacional de La Plata.

Tortti, M.C. (2009) El viejo partido socialista y los orígenes de la "nueva" izquierda. Buenos Aires: Editorial Prometeo. (2014) La nueva izquierda argentina (1955-1976). Socialismo, peronismo y revolución, Rosario: Prohistoria. (2021) "Historia Reciente y nueva izquierda: una revisión”. En: Tortti, M.C. y González Canosa, M. (Dir.), La nueva izquierda en la historia reciente argentina. Debates conceptuales y análisis de experiencias, Rosario: Prohistoria [En prensa], pp.: 17-36.

Varela, J. y Alvarez Uría, F. (1997). Genealogía y sociología, Buenos Aires: El cielo por asalto. Williams, R. (2001) Cultura y Sociedad, Buenos Aires: Nueva Visión. (2003) Palabras clave. Buenos Aires: Nueva Visión (2009) Marxismo y literatura. Barcelona: Península.

\section{Anexo documental (orden alfabético)}

Legajo N 526, Asunto: “Asociación Gremial de Abogados - Foro de Buenos Aires por la vigencia de los derechos humanos. Su origen y vinculación con organizaciones extremistas 'F.A.L.' 'F.A.P.' 'E.R.P.' y 'Montoneros'”, Carpeta Varios, Mesa DS, Archivo DIPBA, Comisión Provincial por la Memoria, La Plata.

Revista De Frente, con las bases peronistas, 1974. Disponible en: www.eltopoblindado.com

Revista Militancia Peronista para la Liberación, 1973-1974. Disponible en: www.eltopoblindado.com

Revista Nuevo Hombre. En: Colección Reediciones y Antologías, Biblioteca Nacional (2015), Nuevo Hombre, Edición Facsimilar, Buenos Aires: Biblioteca Nacional. 
Mariela Stavale

\section{Entrevistas orarles citadas}

Dri, R. Buenos Aires, 09 de octubre de 2014.

Duhalde, M. La Plata, 25 de febrero de 2014.

. La Plata, 22 de septiembre de 2015.

González Gartland, C. Buenos Aires, 09 de octubre de 2016.

Zito Lema, V. Buenos Aires, 14 de octubre de 2013.

. Buenos Aires, 11 de septiembre de 2015. 